\title{
New records of Alvinocarididae (Crustacea: Decapoda: Caridea) from the southwestern Pacific hydrothermal vents, with descriptions of one new genus and three new species
}

\author{
Tomoyuki Komai $^{\mathrm{a} *}$ and Shinji Tsuchida ${ }^{\mathrm{b}}$ \\ ${ }^{a}$ Natural History Museum and Institute, Chiba, Japan; ${ }^{b}$ Japan Agency for Marine-Earth Science \\ and Technology, Yokosuka, Kanagawa, Japan
}

(Received 21 May 2014; accepted 8 January 2015; first published online 5 March 2015)

\begin{abstract}
Three new species of the caridean family Alvinocarididae are described from hydrothermal vents in the Southwest Pacific, namely, Chorocaris parva sp. nov. (Manus Basin, 1305-1684 m), Chorocaris variabilis sp. nov. (Manus and North Fiji basins and Vanuatu, 1305-2480 m) and Manuscaris acuminatus gen. et sp. nov. (Manus Basin, $1310 \mathrm{~m}$ ). Morphological affinities of these three species are discussed. Molecular genetic analysis using partial sequences of the mitochondrial cytochrome c oxidase subunit I (COI) gene supports the recognition of the two new species assigned to Chorocaris Martin and Hessler, 1990. The generic diagnosis of Chorocaris is slightly emended to accommodate the two new species. Opaepele susannae Komai, Gierre and Segonzac, 2007 is transferred to Chorocaris. Alvinocaris komai Zelnio and Hourdez, 2009, originally described from the Lau Basin, is newly recorded from the North Fiji Basin and Vanuatu (Nifonea vent field), at depths of 1740-2750 m.
\end{abstract}

http://zoobank.org/urn:lsid:zoobank.org:pub:4BFC8C31-C006-4738-BED7B13D3296A7CA

Keywords: Chorocaris; Manuscaris; Manus Basin; North Fiji basin; Vanuatu

\section{Introduction}

Members of the caridean family Alvinocarididae exclusively occur in reducing environments in deep water, e.g. hydrothermal vents, brine, sulphide or hydrocarbon seeps (Lunina and Vereshchaka 2014). Most species appear to be restricted to a particular ridge, seamount or seep system, and recent samplings in these habitats have yielded continuous discoveries of new taxa and/or new locality records of this caridean family, which are of considerable interest in systematics and ecology (e.g. Martin and Haney 2005; Komai et al. 2005, 2006, 2007; Ahyong 2009; Zelnio and Hourdez 2009; Komai and Chan 2010; Lunina and Vereshchaka 2010; Nye et al. 2012).

This study reports on new taxa and new records of Alvinocarididae from recent collections made at hydrothermal vent sites in the Southwest Pacific. Three new species are described and illustrated: Chorocaris parva sp. nov. from the Manus Basin; Chorocaris variabilis sp. nov. from the Manus Basin, North Fiji Basin and Vanuatu; and Manuscaris acuminatus gen. nov. et sp. nov. from the Manus Basin. The generic diagnosis of Chorocaris is slightly emended to accommodate the two new

*Corresponding author. Email: komai@chiba-muse.or.jp 
species, C. parva and C. variabilis, and Opaepele susannae Komai et al. 2007; is transferred to Chorocaris. New locality records from the North Fiji Basin and Vanuatu are provided for Alvinocaris komaii Zelnio and Hourdez, 2009; which was originally described from the Lau Basin. Molecular genetic analysis using partial sequences of the mitochondrial cytochrome c oxidase subunit I (COI) gene was performed to confirm the validity of the two new species assigned herein to Chorocaris.

\section{Material and methods}

Collections studied in this work came from various diving cruises organized by American, French, German and Japanese teams: the Japanese YK06-13 cruise to the Manus and North Fiji Basins by DS Shinkai 6500/RV Yokosuka (chief scientist Y. Suzuki, 8 September to 4 October 2006); the American Wave Mercury 2007 (Luk Luk) Campaign to the Manus Basin (chief scientist Cindy Van Dover, Duke University Marine Laboratory); the French-German BIOLAU cruise to the Lau Basin by DS Nautile/RV Nadir (chief scientist A.-M. Alayse, Ifremer, 17 April to 10 May 1989); the French-Japanese STARMER II cruise to the North Fiji Basin by the deep tow camera/ RV Kaiyo (chief scientists D. Desbruyères, Ifremer, and S. Ohta, Ocean Research Institute, University of Tokyo, 30 June to 19 July 1989); and the German RV Sonne SO229 cruise to Vanuatu (chief scientist Karsten Haase, Friedrich-Alexander Universität, 24 June to 26 July 2013). The material examined in this study is deposited in the following institutions: Japan Agency for Marine Science and Technology, Yokosuka, Japan (JAMSTEC); Muséum national d'Histoire naturelle, Paris, France (MNHN); Natural History Museum and Institute, Chiba, Japan (CBM); and Oxford University Museum of Natural History, UK (OUMNH). Specimens used for morphological examination are all preserved in $70 \%$ ethanol. The postorbital carapace length (cl) is used as a standard measurement indicating the size of specimens.

Partial sequences of mitochondrial COI for 16 alvinocaridid taxa are available in the GenBank database. Two specimens of C. parva sp. nov. from the Manus Basin and four specimens of $C$. variabilis sp. nov. (three from the Manus Basin and one from the North Fiji Basin) were used. No specimens of $M$. acuminatus gen. nov. et sp. nov. were available for DNA extraction, because only a single, formalin-fixed specimen was available for study. Genomic DNA of these specimens, stored at $-30^{\circ} \mathrm{C}$ or preserved in $99 \%$ ethanol at room temperature, was extracted from pleonal muscles using the DNeasy Blood \& Tissue Kit (Qiagen, Valencia, CA, USA). Partial sequences of the COI gene $(658 \mathrm{bp})$ were amplified by polymerase chain reaction (PCR) using the universal primers HCO2198 (TAA ACT TCA GGG TGA CCA AAA AAT CA) and LCO1490 (GGT CAA CAA ATC ATA AAG ATA TTG G) (Folmer et al. 1994). The PCR was performed using Ex Taq polymerase (TaKaRa, Tokyo, Japan) with $25-\mu 1$ reaction mixtures containing $2.5 \mu \mathrm{l}$ of $10 \times$ Ex Taq Buffer, $2 \mu \mathrm{dNTP}$ solution, $10 \mathrm{pmol}$ of each primer, $1.25 \mathrm{U}$ of Ex Taq polymerase and sterile water to the final volume. Thermal cycling was carried out on a TaKaRa PCR Thermal Cycler Dice with the following cycle parameters: $95^{\circ} \mathrm{C}$ for $60 \mathrm{~s}$, followed by 35 cycles of $95^{\circ} \mathrm{C}(60 \mathrm{~s}), 48^{\circ} \mathrm{C}(60 \mathrm{~s}), 72^{\circ} \mathrm{C}(90 \mathrm{~s})$; ending with $7 \mathrm{~min}$ at $72^{\circ} \mathrm{C}$. Sequences of PCR products were obtained using the ABI PRISM 3100 DNA Analyzer and the BigDye Terminator Cycle Sequencing Ready Reaction Kit, version 3.1 (PE Biosystems, Foster City, CA, USA). The sequences obtained in this study were deposited in the database of the DNA Data Bank of Japan (DDBJ) under 
accession nos. AB772278-AB772283 and compared with those available in databases using the Basic Local Alignment Search Tool (BLAST) network service to determine approximate phylogenetic affiliations. Sequences were manually aligned, and phylogenetic analyses were restricted to nucleotide positions that were unambiguously alignable in all sequences. Phylogenetic trees based on partial COI sequences (460 bp) were constructed by three methods: (1) maximum likelihood (ML) programmed by the PhyML ver. 3.0, and the bootstrap values were calculated by the same program with the GTR nucleic substitution matrix, four rate categories, BIONJ tree as a starting point for 500 replicates (Guindon et al. 2010); (2) maximum parsimony (MP) estimated using the branch-and-bound search with 1000 replicates bootstrap values by the PAUP 4.0b10 (Swofford 2002); and (3) neighbour-joining (NJ) method using CLUSTAL X 2.1 with 1000 replicates bootstrap values (Thompson 1997). Pairwise estimates of the Kimura-2-Parameter (K2P) distance (Kimura 1980) for inter-specific and intra-specific genetic divergence of the two new species referred to Chorocaris and other closely allied species were calculated by CLUSTAL X 2.1 (Thompson 1997).

For comparison, the following material was examined.

Opaepele loihi Williams and Dobbs, 1995: RV Natsushima, NT10-13 cruise, ROV Hyper-Dolphin, dive \#1161, NW Rota, Mariana Arc, 14³6.071' N, 14446.522' E, $550 \mathrm{~m}$, 26 July 2010, 3 males (cl 7.8-8.7 mm), 7 females (cl 7.0-9.5 mm), JAMSTEC 081482; same cruise, ROV Hyper-Dolphin, dive \#1164, Nikko Seamount, Mariana Arc, $23^{\circ} 04.831^{\prime} \mathrm{N}, 142^{\circ} 19.566^{\prime} \mathrm{E}, 471 \mathrm{~m}, 30$ July 2010, 6 males (cl 7.1-9.9 mm), 23 females (cl 7.2-11.3 mm), 1 juvenile (cl $5.0 \mathrm{~mm}$ ), JAMSTEC 081512.

Opaepele vavilovi Lunina and Vereshchaka, 2010: R/V Akademik Mstislav Keldysh, 50th cruise, DS Mir-1 and Mir-2, stn 4797, Broken Spur, Mid-Atlantic Ridge, 3350 m, 25 August 2005, 2 females (cl 7.7, $10.9 \mathrm{~mm}$ ), paratypes, OMNH 2009-15-0001.

\section{Systematics}

Family ALVINOCARIDIDAE Christoffersen, 1986

Genus Chorocaris Martin and Hessler, 1990

Rimicaris: Williams and Rona 1986: 447 (in part).

Chorocaris Martin and Hessler, 1990: 2; Komai and Segonzac 2008: 32.

Opaepele: Komai et al. 2007: 239 (in part).

Type species

Chorocaris vandoverae Martin and Hessler, 1990.

\section{Composition}

In addition to the type species, the following five species are here assigned to Chorocaris: Chorocaris chacei (Williams and Rona 1986), C. parva sp. nov., Chorocaris paulexa (Martin and Shank 2005), Chorocaris susannae (Komai et al. 2007) comb. nov. and C. variabilis sp. nov. 


\section{Emended diagnosis}

Rostrum reaching or falling short of midlength of first segment of antennular peduncle, dorsoventrally flattened, triangular to rounded in dorsal view; dorsal surface usually non-carinate, always unarmed; ventral surface nearly flat or slightly convex, unarmed. Carapace without postrostral carina; shallow longitudinal depression on either side of midline in spawning females; antennal tooth distinct, varying from acute to blunt; pterygostomial angle produced anteriorly or non-produced; anterior part of branchial region not strongly inflated; pair of dorsal organs evident in postorbital region in living specimens. Pleon with third pleuron unarmed; fourth pleuron unarmed or with one or more denticles posteroventrally; fifth pleuron with posteroventral tooth and occasionally with additional teeth or denticles on posterolateral margin. Telson with dorsolateral spines arranged in sinuous row with second and/or third spines located distinctly mesial to other spines; posterior margin convex, with row of plumose setae flanked by two pairs of lateral spines. Eyes broadly fused, with faint median notch; anterior surface of each eye flat anteriorly, unarmed. Antennular stylocerite clearly separated from first peduncular segment. Antennae usually not forming operculate structure (see Martin and Hessler 1990); antennal scale with sharp to blunt distolateral tooth, clearly separated from lamella or closely approximated to it; transverse suture present, extending mesially from base of distolateral tooth. First maxilliped with rudimentary bud of flagellum on exopod. First pereopod with welldeveloped grooming apparatus on carpus. Second pereopod without spine on ischium. Third to fifth pereopods increasing in length posteriorly; dactyli each with two or more rows of accessory spinules on flexor surfaces; meri of third and fourth pereopods unarmed; ischia of third and fourth pereopods unarmed (except for males of $C$. variabilis sp. nov.). No strap-like epipods on third maxilliped or first to fourth pereopods. Appendix interna on fourth pleopod without terminal cluster of coupling hooks. Uropodal exopod with two posterolateral spines mesial to posterolateral tooth; protopod sharply to bluntly pointed posterolaterally.

\section{Distribution}

Hydrothermal vents in the western and eastern Pacific and on the Mid-Atlantic Ridge; 1305-3650 m.

\section{Remarks}

The genus Chorocaris was established by Martin and Hessler (1990) to accommodate the type species $C$. vandoverae from hydrothermal vents in the Mariana Back Arc Basin, and Rimicaris chacei Williams and Rona, 1986 from hydrothermal vents along the Mid-Atlantic Ridge. Chorocaris was differentiated from Rimicaris by the more-developed rostrum, the non-inflated branchial regions of the carapace, the cylindrical fused eyestalks and the non-operculate antennae (Martin and Hessler 1990). A new species Chorocaris fortunata Martin and Christiansen, 1995 was subsequently described from the Lucky Strike vent field on the Mid-Atlantic Ridge, but this species was later transferred to Mirocaris by Vereshchaka (1997). Based on analyses of the COI gene (600 bp), Shank et al. (1999) proposed that Chorocaris is a paraphyletic assemblage with $C$. chacei being more closely related to 
Rimicaris exoculata than to $C$. vandoverae. Martin and Shank (2005) described a new species, $C$. paulexa, from the Rapa Nui Homer Vent Site on the southern East Pacific Rise. Komai et al. (2007) then described a new species, Opaepele susannae Komai et al. 2007, from the southern Mid-Atlantic Ridge, and suggested that their new species appears to be intermediate between Chorocaris and Opaepele. Komai and Segonzac (2008) reviewed Chorocaris and Rimicaris, and took a conservative approach by recognizing three species in Chorocaris, namely, $C$. chacei, $C$. paulexa and $C$. vandoverae; these authors maintained the genus despite the possibility of it being paraphyletic. Recently, a new species, Rimicaris hybisae Nye, Copley and Plouviez, 2012, was described from the Mid-Cayman Spreading Centre, in the Caribbean; this species was provisionally referred to Rimicaris, but exhibits some similarities to $C$. chacei (see Nye et al. 2012).

The discovery of the two new species, herein referred to Chorocaris, led us to reassess the characters that differentiate the genera Chorocaris and Opaepele. Comparison of $C$. vandoverae and Opaepele loihi, the type species of the respective genera, has confirmed the following morphological differences: (1) the rostrum is devoid of a dorsal carina or dorsal teeth or denticles in C. vandoverae, whereas in $O$. loihi, the rostrum has a distinct dorsal carina, extending to the postrostral part of the carapace, and occasionally bears minute denticles; (2) the uropodal exopod always bears two movable spines at the posterolateral angle in $C$. vandoverae, whereas there is usually one, rarely two, movable spines just mesial to the fixed posterolateral tooth in $O$. loihi. The two previously known species of Chorocaris (C. chacei and $C$. paulexa), O. susannae and the two new species of Chorocaris described herein are morphologically akin to $C$. vandoverae in these regards.

The lack of a dorsal carina on the rostrum and the possession of two posterolateral spines on the uropodal endopod are presumed to be apomorphic within the Alvinocarididae (cf. Komai and Segonzac 2003, 2004, 2008). Consequently, Opaepele loihi is set apart from a group, which includes Opaepele susannae, Chorocaris species including the two new species described herein, and Rimicaris species. Despite the suggested paraphyly of Chorocaris, we recognize Chorocaris as a valid genus for the time being, including $C$. vandoverae, $C$. chacei, $C$. paulexa, $C$. parva sp. nov., $C$. variabilis sp. nov. and $C$. susannae comb. nov. until thorough phylogenetic analysis is performed.

In addition, Opaepele vavilovi has a number of presumably plesiomorphic characters, such as the dorsolateral spines on the telson being arranged in a linear row, the presence of a spiniform tubercle on the rounded anterior surface of each eye, the possession of meral and/or ischial spines on the second to fourth pereopods and the presence of a single row of accessory spinules on the dactyli of the third to fifth pereopods. In these regards, $O$. vavilovi is similar to species of Alvinocaris, and could be excluded from a group of genera containing Alvinocaridinides, Chorocaris, Opaepele, Rimicaris and Shinkaicaris. Future study has the potential to warrant the establishment of a separate genus for O. vavilovi.

Chorocaris parva sp. nov.

(Figures 1-5) 


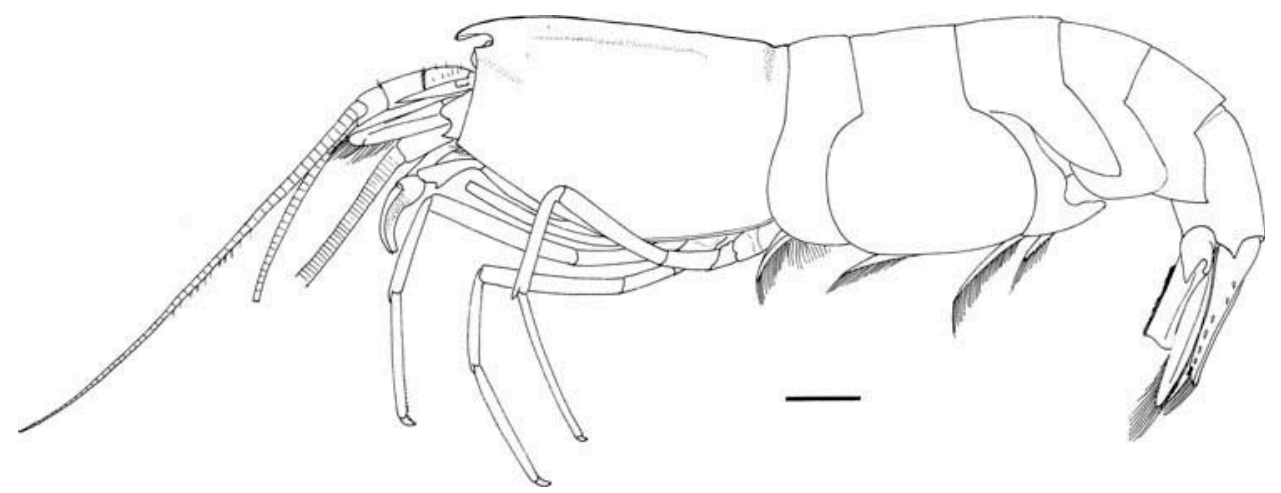

Figure 1. Chorocaris parva sp. nov., holotype, ovigerous female (carapace length $8.0 \mathrm{~mm}$ ), CBM-ZC 11939, entire animal in lateral view (third and fourth pleonal pleura and left uropod partially damaged). Scale bar $=2 \mathrm{~mm}$.

\section{Material examined}

Holotype. Wave Mercury 2007 (Luk Luk) Campaign, dive 28, South Su site, Manus Basin, Bismarck Sea, 03 $08.09^{\prime} \mathrm{S}, 152^{\circ} 10.5^{\prime} \mathrm{E}, 1310 \mathrm{~m}, 10$ April 2007, ovigerous female (cl $8.0 \mathrm{~mm})$, CBM-ZC 11,939.

\section{Paratype}

Manus Basin. Same data as holotype, 1 male (cl 6.9 mm), CBM-ZC 11940; same data as holotype, 33 males (cl 4.3-6.8 mm), CBM-ZC 11941; same data as holotype, 18 females (cl 4.5-7.8 mm), 5 ovigerous females (cl 5.7-6.7 mm), CBM-ZC 11942; dive 30, South Su, 308.09' S, 152 10.5' E, 1305 m, 11 April 2007, 2 males (cl 5.2, 5.9 mm), 1 female (cl 7.1 mm), CBM-ZC 11944; dive 34, same site, 1310 m, 14 April 2007, 14 males (cl 4.3-6.8 mm), 11 females (cl 4.0-7.5 mm), 3 ovigerous females (cl 5.56.5 mm), OUMNH.ZC.2014-01-014. RV Yokosuka, YK06-13 cruise, DS Shinkai

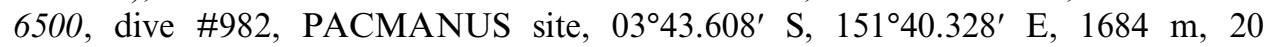
September 2006, 2 specimens (not measured; DNA extracted, preserved in frozen condition), JAMSTEC 070101-070102.

\section{Description}

Body integument with scattered minute setae.

Rostrum (Figures 2A, B; 5A, B) reaching (males) or falling short of (females) midlength of first segment of antennular peduncle, tip blunt in dorsal view; ventral surface slightly convex; lateral margin merging into orbital margin. Carapace (Figures 1, 2A-C; 5A, B) with dorsal surface slightly sloping down anteriorly to rostrum, almost glabrous or with few minute setae anteriorly; orbital margin evenly concave; antennal tooth acute or subacute; pterygostomial angle not markedly produced, terminating in subacute or acute point.

Third pleonal pleuron (Figures 1, 2D) broadly rounded; fourth pleuron with blunt or subacute posteroventral angle, no additional denticles; fifth pleuron with 

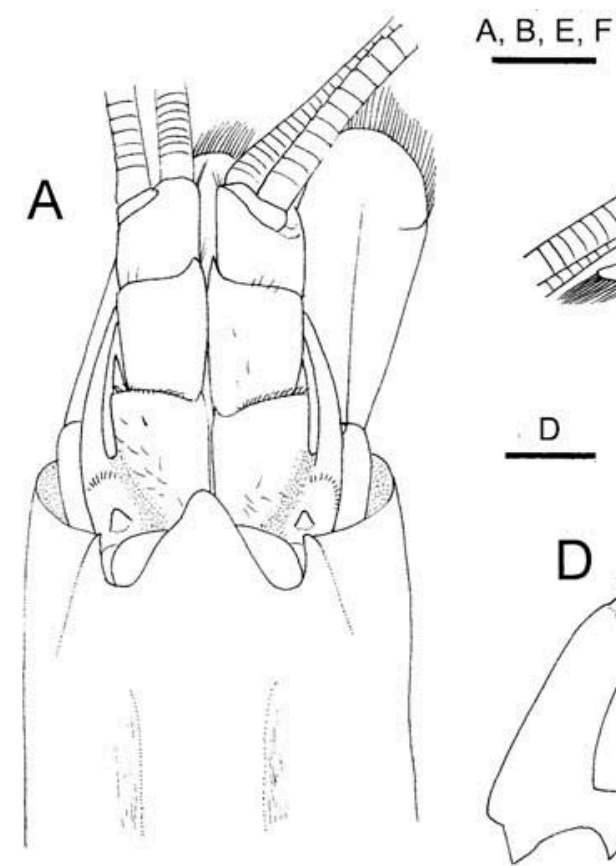

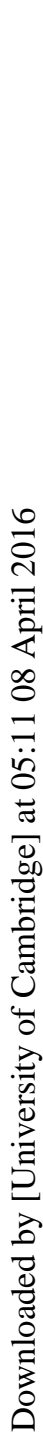
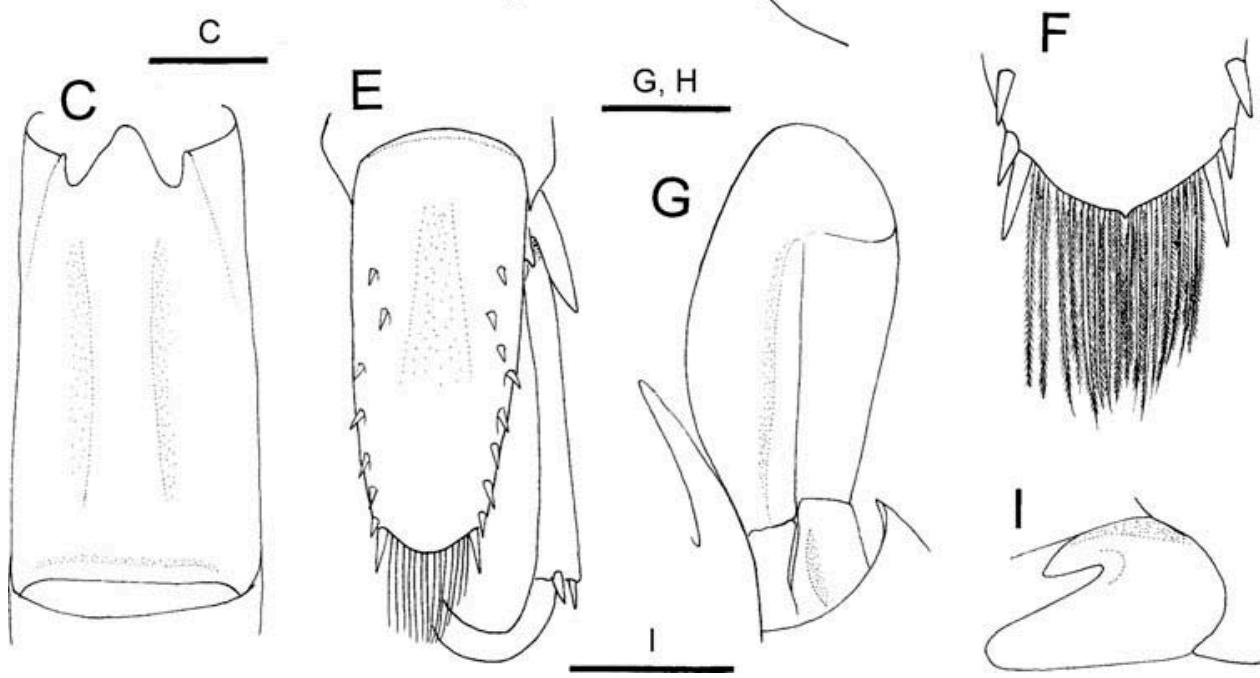

Figure 2. Chorocaris parva sp. nov., holotype, ovigerous female (carapace length $8.0 \mathrm{~mm}$ ), CBM-ZC 11939. (A) Anterior part of carapace and cephalic appendages, dorsal view; (B) same, lateral view; (C) carapace, dorsal view; (D) fourth to sixth pleomeres, right side, lateral view; (E) telson and right uropod, dorsal view (marginal setae on uropod omitted); (F) posterior margin of telson, dorsal view; $(\mathrm{G})$ right antennal scale, dorsal view (setae omitted); $(\mathrm{H})$ distolateral tooth of right antennal scale, dorsal view; (I) protopod of right uropod, dorsolateral view. Scale bars: $2 \mathrm{~mm}$ for C; $1 \mathrm{~mm}$ for A, B, D, E, G, I; $0.5 \mathrm{~mm}$ for F, H. 

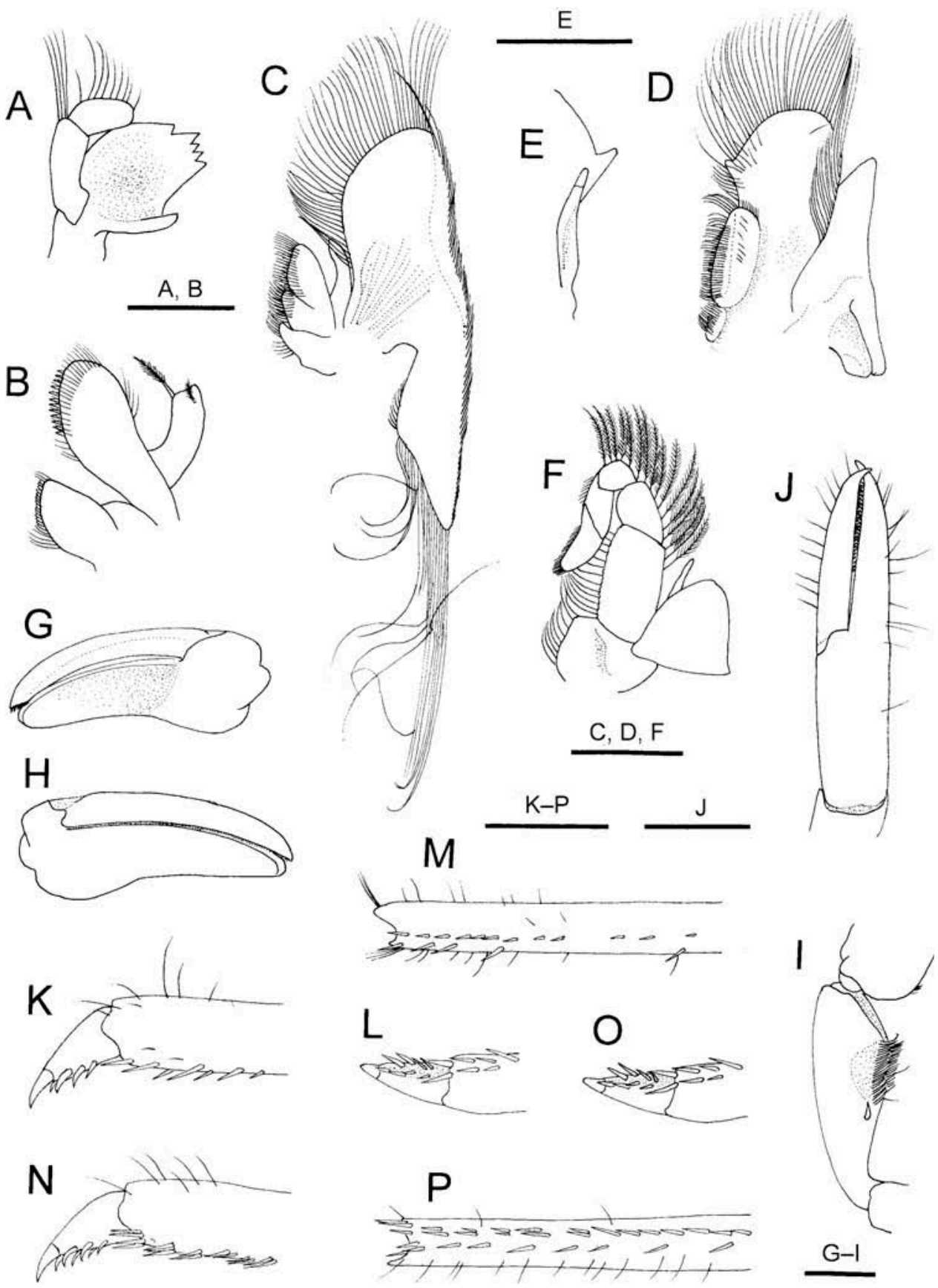

Figure 3. Chorocaris parva sp. nov., holotype, ovigerous female (carapace length $8.0 \mathrm{~mm}$ ), CBM-ZC 11939. (A) Left mandible, inner view; (B) left maxillule, outer view; (C) left maxilla, outer view; (D) left first maxilliped, outer view; (E) same, endopod, inner view; (F) left second maxilliped, outer view; (G) chela of left first pereopod, inner (flexor) view; (H) same, outer (extensor) view; (I) carpus of left first pereopod, mesial view, showing grooming apparatus; (J) chela of left second pereopod, extensor view; (K) dactylus and propodus of left third pereopod, lateral view; (L) same, flexor view; (M) distal part of propodus of left third pereopod, obliquely flexor view; $(\mathrm{N})$ dactylus and distal part of propodus of left fifth pereopod, lateral view; (O) same, flexor view; (P) propodus of left fifth pereopod, flexor view. Scale bars: $1 \mathrm{~mm}$ for C-F; $0.5 \mathrm{~mm}$ for A, B, G-P. 


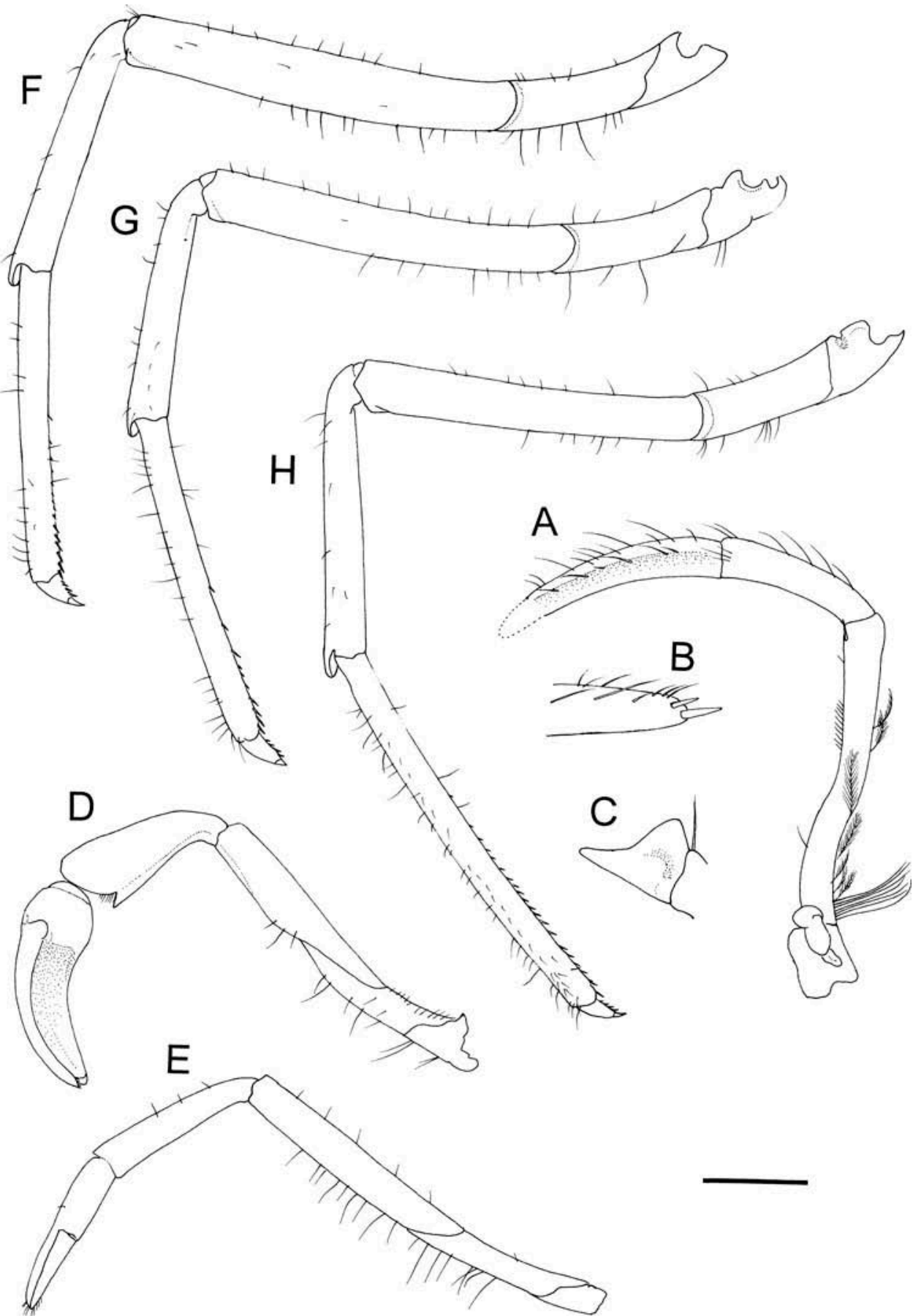

Figure 4. Chorocaris parva sp. nov., holotype, ovigerous female (carapace length $8.0 \mathrm{~mm}$ ), CBM-ZC 11939. (A) Left third maxilliped, lateral view (distal part of ultimate segment damaged); (B) close up of distal part of ultimate segment of right third maxilliped, lateral view; (C) epipod of left third maxilliped, dorsal view; (D) left first pereopod, lateral view; (E) left second pereopod, lateral view; (F) left third pereopod, lateral view; (G) left fourth pereopod, lateral view; $(\mathrm{H})$ left fifth pereopod, lateral view. Scale bars: $1 \mathrm{~mm}$ for A, D-H; $0.5 \mathrm{~mm}$ for B, C. 


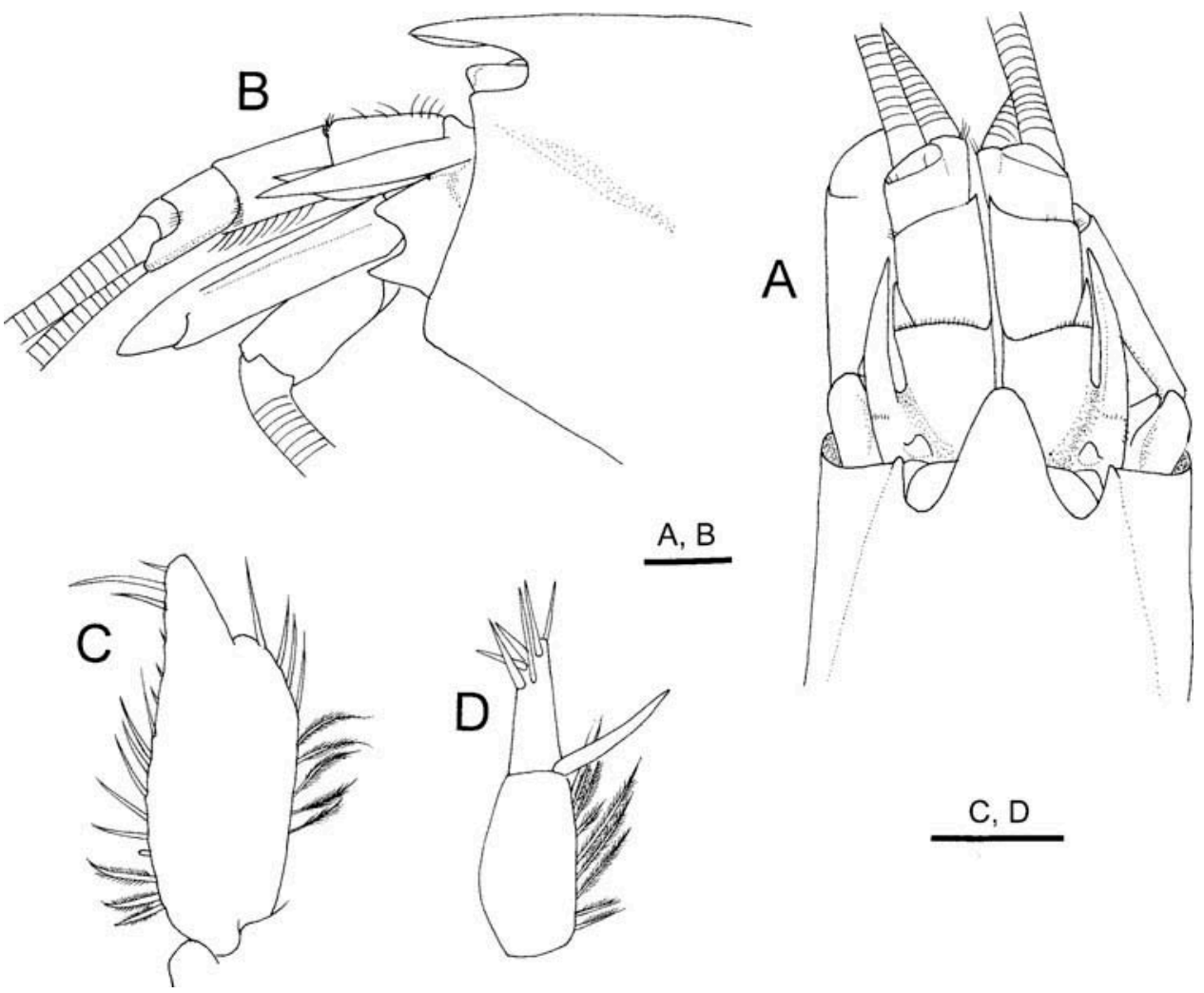

Figure 5. Chorocaris parva sp. nov., paratype, male (carapace length $6.9 \mathrm{~mm}$ ), CBM-ZC 11940. (A) Anterior part of carapace and cephalic appendages, dorsal view (setae on antennal scale omitted); (B) same, lateral view; (C) endopod of left first pleopod, dorsal view; (D) appendices interna and masculina of left second pleopod, mesial view. Scale bars: $1 \mathrm{~mm}$ for A, B; $0.5 \mathrm{~mm}$ for C, D.

posterolateral angle produced into sharp or blunt tooth (sometimes different between right and left), posterior margin above angle slightly sinuous or slightly convex, unarmed. Sixth pleomere 1.4-1.5 times longer than fifth pleomere and 1.4-1.5 times longer than high, with acute posteroventral tooth, posterolateral process terminating in sharp tooth. Telson (Figure 2E) falling well short of posterior margins of uropods, slightly narrowed posteriorly, about 2.5 times longer than anterior width, armed with six to eight dorsolateral spines; posterior margin convex, with two pairs of spines at lateral angles (mesial pair longer than lateral pair), minute median tooth, and 20-24 long plumose setae (Figure 2F).

Eyes (Figure 2A,B) broadly fused with faint median notch, lacking setae on anterior surface.

Antennular peduncle (Figure 2A, B) stout, falling slightly short of or reaching distal margin of antennal scale. First segment with moderately large distolateral tooth and small distomesial tooth and blunt proximolateral tubercle; stylocerite slender, slightly curved mesially, nearly reaching distal margin of second segment. 
Second segment with distomesial tooth larger than corresponding tooth on first segment.

Antennal peduncle (Figure 2A, B, G) stout. Basicerite with ventrodistal tooth extending as far as dorsodistal projection and often with blunt tooth arising from ventral surface. Fifth segment (= carpocerite) slightly overreaching midlength of antennal scale. Antennal scale suboval, 0.3-0.4 times as long as carapace, about 2.0 times longer than wide; distolateral tooth acute or subacute, closely approximated to lamella (Figure 2H).

Mouthparts typical of family (for detailed description, see Komai and Segonzac 2003, 2005; Komai et al. 2007), as figured (Figure 3A-F). Endopod of maxillule with one apical plumose seta at inner distal angle and one subterminal seta arising from base of outer lobule (Figure 3B). Maxilla (Figure 3C) with moderately broad scaphognathite, devoid of bacteriophore setae on ventral surface; posterior lobe elongate, triangular. Endopod of first maxilliped somewhat compressed, twoarticulated (Figure 3E). Second maxilliped (Figure 3F) with moderately stout endopod; epipod roundly triangular, with simple rudimentary podobranch. Third maxilliped (Figure 4A) not reaching distal margin of antennal scale, moderately slender; ultimate segment tapering distally in subtruncate tip bearing two unequal spines (Figure 4B), with row of spiniform setae on lateral ridge; epipod unequally bilobed (Figure 4C).

First pereopod (Figure 4D) moderately slender, not polymorphic, reaching beyond antennal carpocerite by length of fingers, otherwise typical of family; chela (Figure 3G, H) subequal in length to carpus. Second pereopod (Figure 4E) extending to near distal end of antennal scale; chela and carpus about equal in length; fingers each terminating in distally curved, crossing tip, cutting edge pectinated with row of minute spinules; dactylus about 1.1 times as long as palm (Figure 3J). Third pereopod (Figure 4F) overreaching antennal scale by full length of propodus; dactylus somewhat compressed laterally, $0.15-0.20$ times as long as propodus, terminating in strong, curved unguis, flexor surface with six to ten spinules arranged in two rows (Figure 3K, L); propodus with two rows of spinules on flexor surface, mesial row with fewer spinules (Figure 3M); carpus $0.70-0.75$ times as long as propodus; ischium usually unarmed, but rarely with one minute spine ventrolaterally. Fourth pereopod (Figure 4G) similar to third pereopod in structure; ischium always unarmed. Fifth pereopod (Figure $4 \mathrm{H}$ ) generally similar to third and fourth; dactylus similar to those of third and fourth pereopods (Figure $3 \mathrm{~N}, \mathrm{O}$ ); propodus with lateral row of spinules consisting of six sets of two or three spinules followed by a single row of spinules, mesial row consisting of more widely spaced spinules (Figure 3P); propodus and carpus combined distinctly longer than merus and ischium combined; ischium always unarmed.

Endopod of male first pleopod (Figure 5C) bilobed distally, mesial lobe prominent, with three or four long spiniform setae directed mesially, lateral lobe obsolete; mesial margin with row of spiniform setae, proximal few plumose, lateral margin with four spiniform setae in distal 0.3 and with some plumose setae in proximal 0.6. Appendix masculina of second pleopod (Figure 5D) stout, subequal in length to appendix interna, armed distally with six to eight spiniform setae. Uropod (Figure 2E) with protopod bearing terminally blunt posterolateral process; exopod with two subequal spines at posterolateral angle. 
Size

Males cl 4.3-6.8 mm; females cl 3.2-7.8 mm, ovigerous females cl 5.7-6.7 mm.

\section{Coloration}

Not known.

\section{Distribution}

Known only from two hydrothermal vent sites in Manus Basin, southwestern Pacific: South Su site, 1305-1310 m; PACMANUS site, $1684 \mathrm{~m}$ depth.

\section{Remarks}

Chorocaris parva sp. nov. is morphologically most similar to C. susannae comb. nov. known from the southern Mid-Atlantic Ridge in having the pterygostomial angle of the carapace only slightly produced, having less numerous accessory spinules on the flexor faces of the third to fifth pereopods (six to eight arranged in two rows versus 10-16 arranged in three or four rows) and in its relatively small body size (maximum $\mathrm{cl}<8.0 \mathrm{~mm}$ ). In the other four species of Chorocaris, the pterygostomial angle of the carapace is produced into a prominent tooth $(C$. paulexa, $C$. vandoverae and $C$. variabilis sp. nov.) or a broadly rounded lobe (C. chacei); and the body size is larger (attaining more than $8.0 \mathrm{~mm} \mathrm{cl}$ ). This new species is morphologically distinguished from $C$. susannae by the following characters: (1) the fourth pleonal pleuron is unarmed in $C$. parva, rather than armed with a posteroventral tooth and additional marginal denticles as in $C$. susannae; (2) the fifth pleonal pleuron bears only a posteroventral tooth in $C$. parva, whereas it is armed with up to three denticles on the posterolateral margin in addition to having a posteroventral tooth in $C$. susannae, is frequently only bluntly pointed in C. parva, rather than terminating in an acute tooth in C. susannae.

\section{Etymology}

The Latin parvus (= small), in reference to the small body size of this new species.

Chorocaris variabilis sp. nov.

(Figures 6-10)

Chorocaris sp. - Zelnio and Hourdez 2009: 52.

\section{Material examined}

Holotype. Wave Mercury 2007 (Luk Luk) Campaign, dive 28, South Su, Manus Basin, Bismarck Sea, $03^{\circ} 08.09^{\prime} \mathrm{S}, 152^{\circ} 10.5^{\prime} \mathrm{E}, 1310 \mathrm{~m}, 10$ April 2007, female (cl $13.6 \mathrm{~mm})$, CBM-ZC 11,945. 


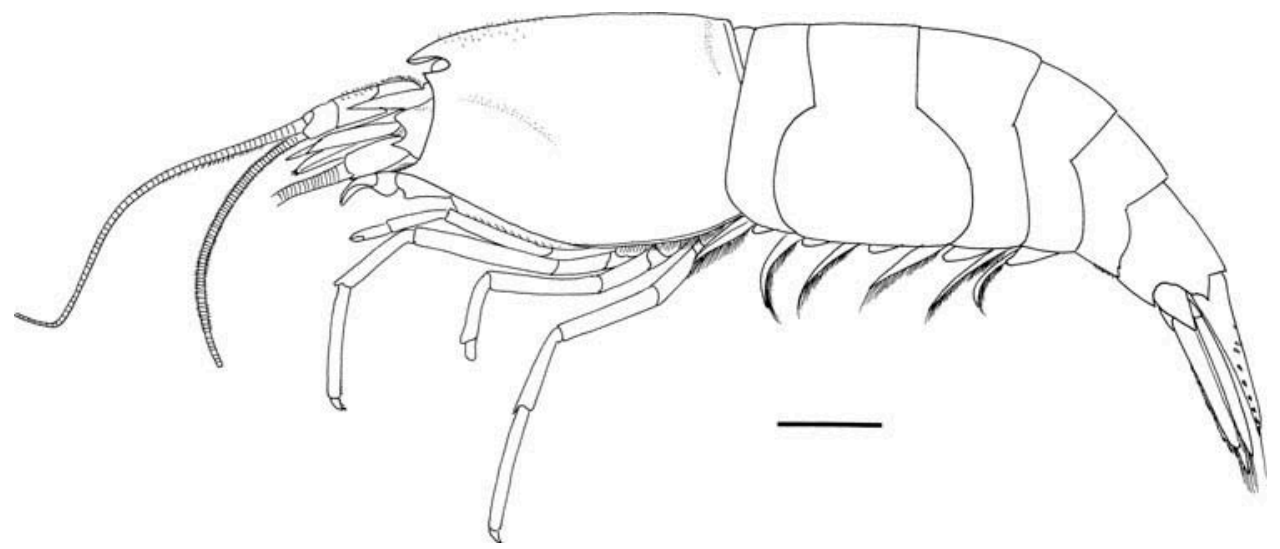

Figure 6. Chorocaris variabilis sp. nov., holotype, female (carapace length $13.6 \mathrm{~mm}$ ), CBM-ZC 11945, entire animal in lateral view (fourth pereopod in process of regeneration). Scale bar: $5 \mathrm{~mm}$.

\section{Paratypes}

Manus Basin. Wave Mercury 2007 (Luk Luk) Campaign, same data as holotype, 10 males (cl 5.2-9.1 mm), CBM-ZC 11946; same data as holotype, 14 females (cl 6.5-12.9 mm), 6 ovigerous females (cl 10.7-13.5 mm), CBM-ZC 11947; dive 30, South $\mathrm{Su}, 3^{\circ} 08.09^{\prime} \mathrm{S}, 152^{\circ} 10.5^{\prime} \mathrm{E}, 1305 \mathrm{~m}, 11$ April 2007, 9 males (cl 10.6$11.9 \mathrm{~mm}$ ), CBM-ZC 11948; same data, 6 females (cl 13.3-15.0 mm), 1 ovigerous female (cl $12.8 \mathrm{~mm}$ ), CBM-ZC 11949; dive 34, same site, $1310 \mathrm{~m}, 14$ April 2007, 13 males (cl 6.6-9.0 mm), 9 females $(\mathrm{cl} 5.0-12.0 \mathrm{~mm}), 1$ ovigerous female $(\mathrm{cl}$ $9.6 \mathrm{~mm}$ ), CBM-ZC 11950; dive 53, Solwara 1, 0307.91' N, $152^{\circ} 09.1^{\prime} \mathrm{E}, 1570 \mathrm{~m}$, 25 April 2007, 27 males (cl 5.1-7.5 mm), CBM-ZC 11951; same data, 26 females (cl 4.4-10.4 mm), 14 ovigerous females (cl 6.7-9.4 mm), CBM-ZC 11952; same data, 22 males (cl 4.8-7.2 mm), 14 females (cl 5.2-12.0 mm), 3 ovigerous females (cl 9.6-14.0 mm), OUMNH.ZC.2014-01-015. RV Yokosuka, YK06-13 cruise, DS Shinkai 6500, dive \#978, PACMANUS site, 034․ $60^{\prime} \mathrm{S}, 151^{\circ} 40.32^{\prime} \mathrm{E}, 1683 \mathrm{~m}, 16$ September 2006, 1 male (cl $8.2 \mathrm{~mm}), 1$ female $(\mathrm{cl} 7.6 \mathrm{~mm}), 1$ ovigerous female (cl $10.8 \mathrm{~mm}$ ), JAMSTEC 066720-066722; DS Shinkai 6500, dive \#981, Vienna Woods, $03^{\circ} 09.813^{\prime} \mathrm{S}, 151^{\circ} 16.737^{\prime} \mathrm{E}, 2480 \mathrm{~m}, 14$ September 2006, 1 ovigerous female (cl $10.3 \mathrm{~mm}$ ), JAMSTEC 068873; DS Shinkai 6500 dive \#982, PACMANUS site, $03^{\circ} 43.608^{\prime} \mathrm{S}, 151^{\circ} 40.328^{\prime} \mathrm{E}, 1684 \mathrm{~m}, 20$ September 2006, 3 specimens (not measured; DNA extracted, preserved in frozen condition), JAMSTEC 070103-070105. North Fiji Basin. RV Yokosuka, YK06-13 cruise, DS Shinkai 6500, dive \#985, Mussel Hill site, 1654.444' S, 17354.895' E, 1988 m, 2 October 2006, 8 males (cl 4.9-7.1 mm), 2 females (cl 5.4, 7.0 mm), JAMSTEC 070543-070552; same data, 1 specimen (not measured; DNA extracted, preserved in 99\% ethanol), JAMSTEC 070543. Vanuatu. RV Sonne, SO229-060-N201, Nifonea vent field, $18^{\circ} 07.735^{\prime} \mathrm{S}, 169^{\circ} 31.112^{\prime} \mathrm{E}, 1873 \mathrm{~m}, 14$ July 2013, 9 males (cl 6.6-9.3 mm), 3 females (cl 6.7-7.7 mm), 1 ovigerous female (cl $7.6 \mathrm{~mm}$ ), CBMZC 12,481. 


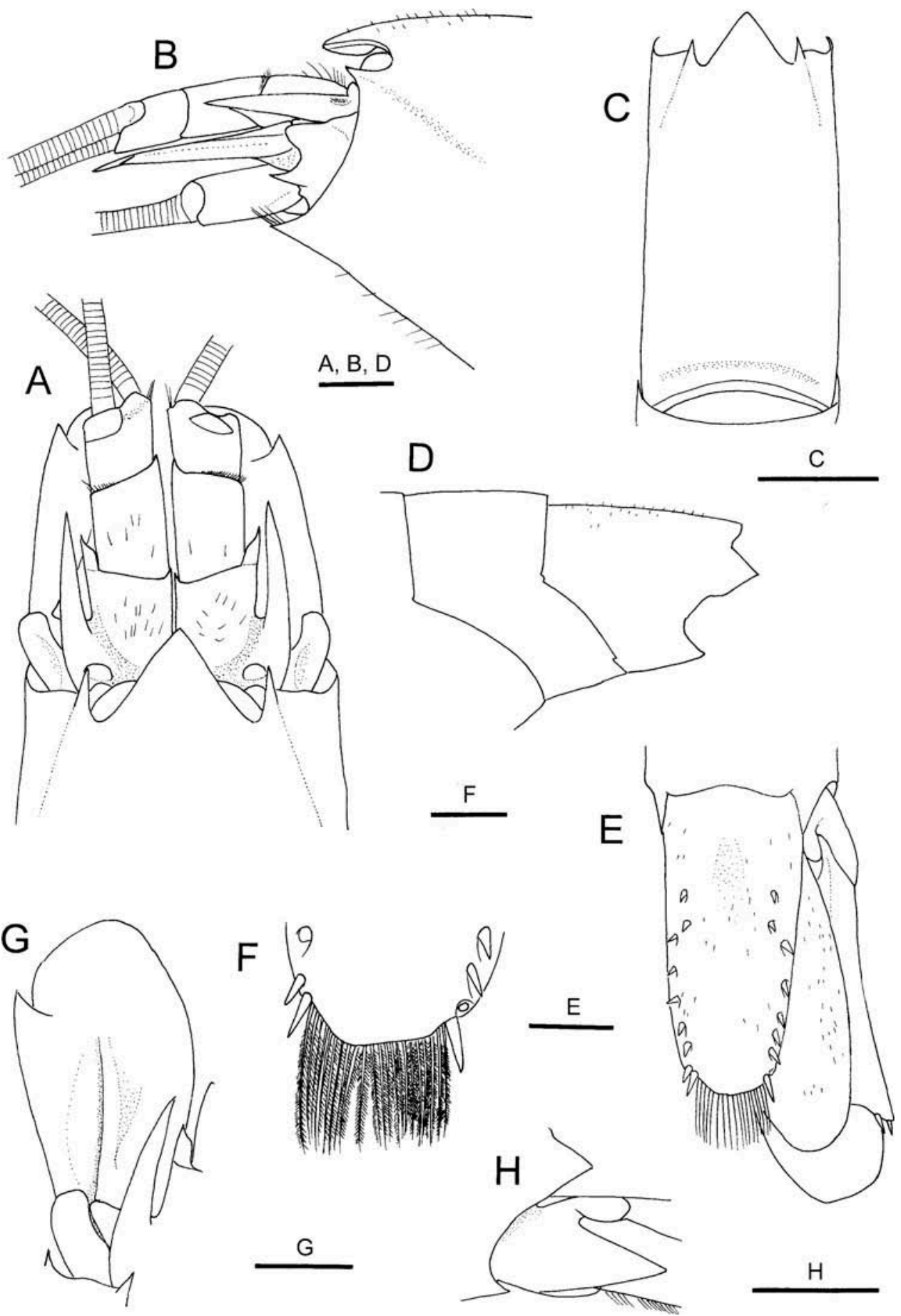

Figure 7. Chorocaris variabilis sp. nov., holotype, female (carapace length $13.6 \mathrm{~mm}$ ), CBM-ZC 11945. (A) Anterior part of carapace and cephalic appendages, dorsal view; (B) same, lateral view; (C) carapace, dorsal view; (D) fifth and sixth pleomeres, left side, lateral view; (E) telson and right uropod, dorsal view (marginal setae on uropod omitted); (F) posterior part of telson, dorsal view (slightly deformed); (G) left antennal scale, dorsal view (setae omitted); $(\mathrm{H})$ protopod of right uropod, dorsolateral view. Scale bars: $5 \mathrm{~mm}$ for C; $2 \mathrm{~mm}$ for A, B, D, E, G, H; $1 \mathrm{~mm}$ for F. 

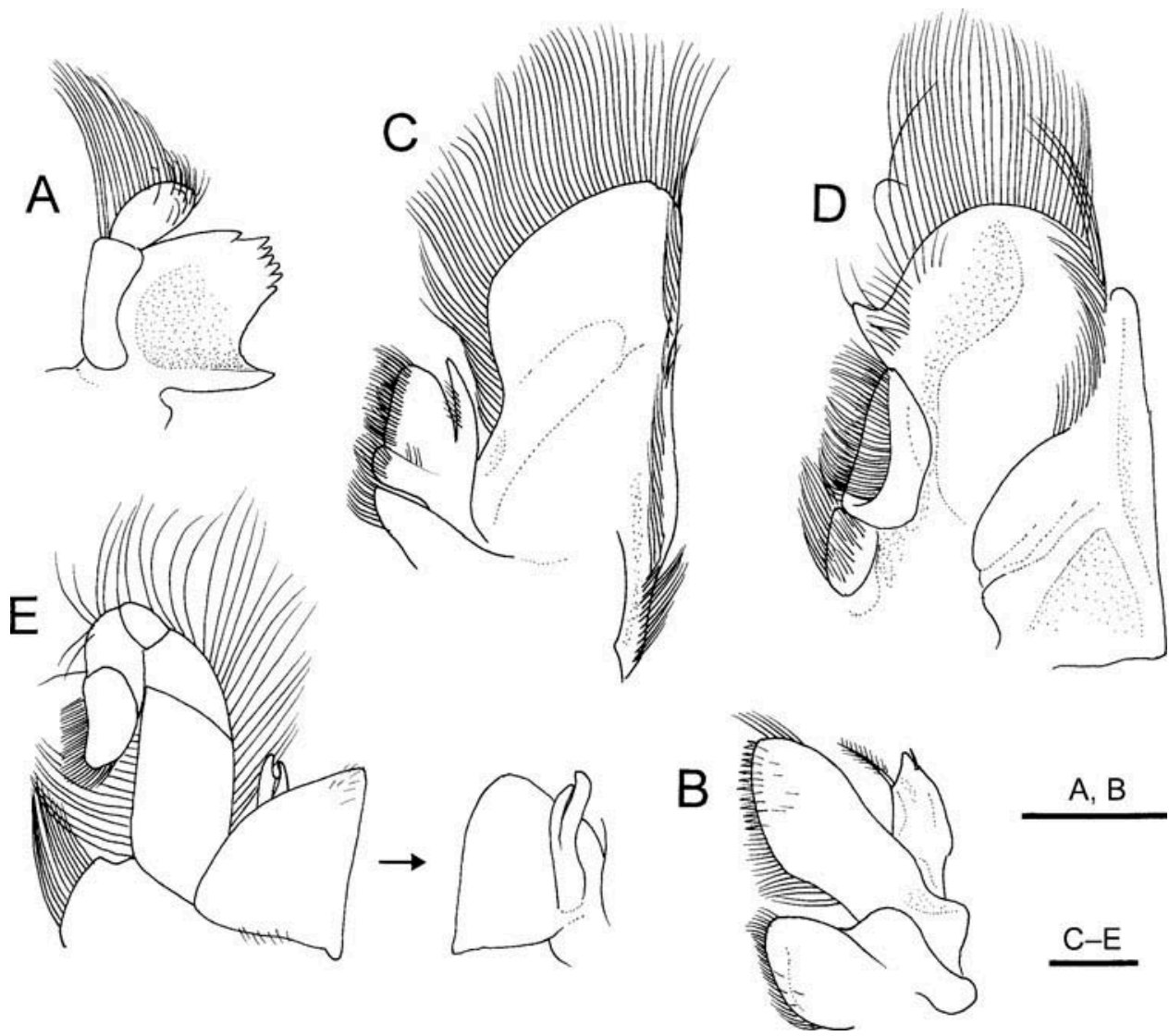

Figure 8. Chorocaris variabilis sp. nov., holotype, female (carapace length $13.6 \mathrm{~mm}$ ), CBM-ZC 11945. Left mouthparts. (A) Mandible, inner view; (B) maxillule, outer view; (C) maxilla, outer view (posterior lobe of scaphognathite broken off); (D) first maxilliped, outer view; (E) left second maxilliped, outer view; inset, epipod and podobranch, inner view. Scale bars: $1 \mathrm{~mm}$.

Non-type. Vanuatu: same data as CBM-ZC 12481, 2 juveniles (cl 3.8, 3.9 mm), CBMZC 12,482.

\section{Description}

Females. Body integument smooth, shiny, fairly thin, with scattered short setae, more numerous on dorsal side.

Rostrum (Figure 7A-C) falling slightly short of midlength of first segment of antennular peduncle, triangular in dorsal view; tip varying from blunt (ovigerous females) to acute or subacute (non-ovigerous females); dorsal surface smooth. Carapace (Figures 6, 7A-C, 10G-J) compressed laterally; dorsal surface sloping down anteriorly to rostrum; antennal tooth triangular, acute (non-spawning females) or acute to blunt (spawning females); pterygostomial angle strongly produced 

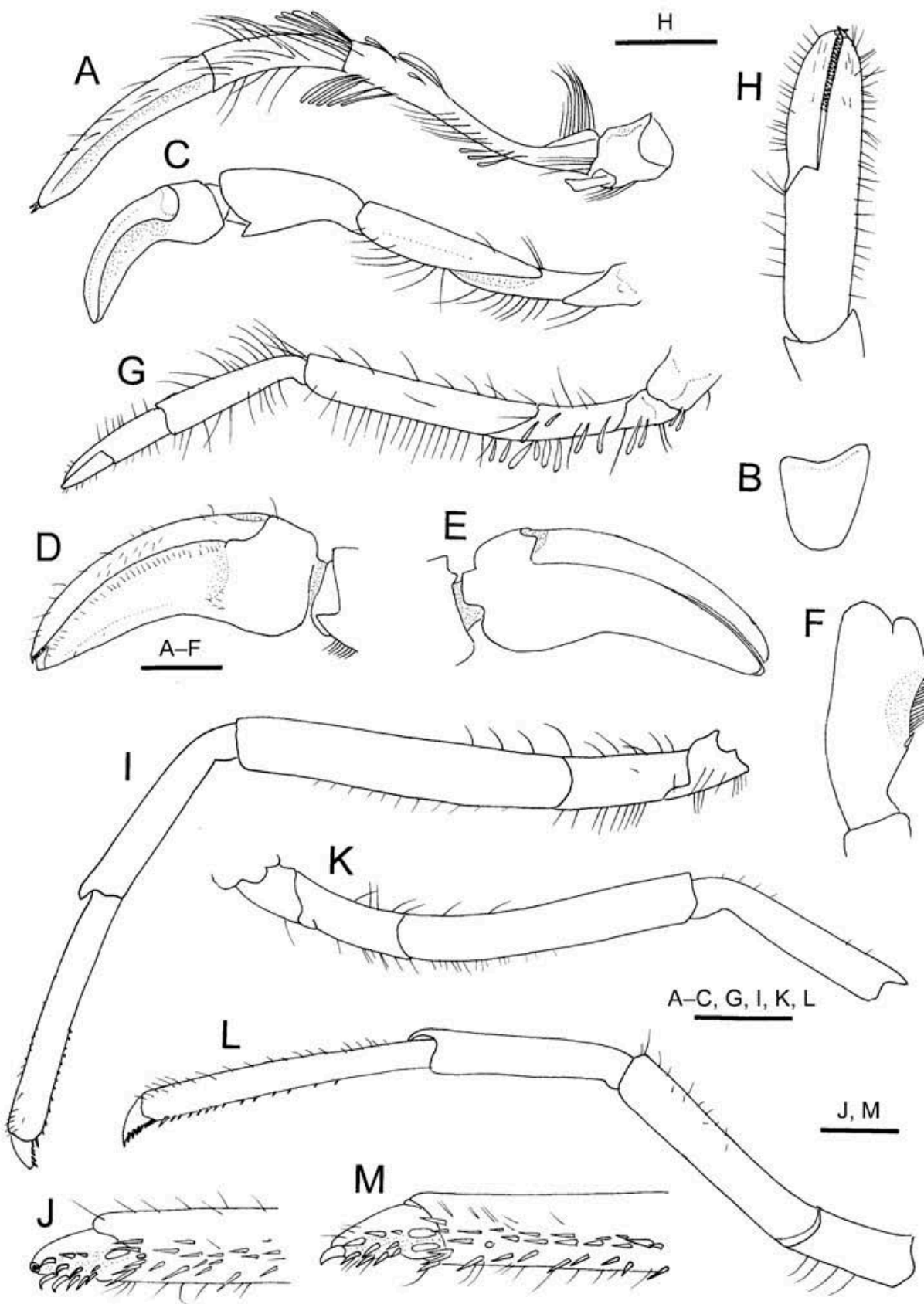

Figure 9. Chorocaris variabilis sp. nov., holotype, female (carapace length $13.6 \mathrm{~mm}$ ), CBM-ZC 11945. (A) Left third maxilliped, lateral view; (B) same, epipod, dorsal view; (C) left first pereopod, lateral view; (D) same, chela, inner (flexor) view; (E) same, outer (extensor) view; (F) same, carpus, mesial view, showing grooming apparatus; $(\mathrm{G})$ left second pereopod, lateral view; (H) same, chela, extensor view; (I) left third pereopod, lateral view; (J) same, dactylus and distal part of propodus, flexor view; (K) right fourth pereopod (distal 2 segments missing); (L) left fifth pereopod, lateral view; (M) same, dactylus and distal part of propodus, flexor view. Scale bars: $2 \mathrm{~mm}$ for A-C, G, I, K, L; $1 \mathrm{~mm}$ for D-F, H; $0.5 \mathrm{~mm}$ for J, M. 
anteriorly in acute or subacute tooth extending as far as dorsolateral process of antennal basicerite.

Third pleonal pleuron (Figure 6) broadly rounded, always unarmed; fourth pleuron rounded or bluntly angular posteroventrally, without sharp tooth (Figures $7 \mathrm{D}, 10 \mathrm{~K})$; fifth pleuron usually with small posteroventral tooth and with zero to four tiny denticles on sinuous to convex posterolateral margin (Figures 7D, 10K). Sixth pleomere (Figure 7D) about 1.2 times longer than fifth pleomere and about 1.1 times longer than high, having acute or subacute posteroventral tooth, posterolateral process terminating in sharp tooth. Telson (Figure 7E) about 2.2 times longer than anterior width, falling short of posterior margins of uropods, very slightly narrowed posteriorly, normally armed with six to eight dorsolateral spines arranged in sinuous row; posterior margin convex, occasionally with minute median denticle or tooth and with two pairs of spines at lateral angles and 20-24 long plumose setae (Figure 7F).

Eyes (Figure 7A, B) lacking setae on anterior surface. Antennular peduncle (Figure 7A, B) stout, reaching distal margin of antennal scale; first segment with moderately large distolateral and small distomesial teeth and prominent, blunt proximolateral tubercle; stylocerite slender, nearly straight, falling slightly short of distal margin of second segment; second segment 1.0-1.1 times as long as wide, with distomesial tooth subequal in size to corresponding tooth on first segment; flagella moderately slender. Antennal peduncle (Figure 7A, B, G) stout; basicerite with ventrodistal tooth overreaching dorsodistal projection; fifth segment (= carpocerite) slightly overreaching midlength of antennal scale; antennal scale suboval, about 0.4 times as long as carapace, 1.6 times longer than wide, lateral margin almost straight, but convex near distolateral tooth, distolateral tooth acute or subacute, clearly separated or approximated to lamella.

Mouthparts generally similar to those of $C$. parva sp. nov., as figured (Figures 8A-E, 9A). Second maxilliped (Figure 8E) relatively stout. Epipod of third maxilliped nearly trapezoidal, slightly unequally bilobed (Figure 9B).

First pereopod (Figure 9C-E) reaching or slightly overreaching midlength of antennal scale, moderately slender to robust, polymorphic as in $C$. vandoverae and C. paulexa. Second to fifth pereopods relatively stout. Second pereopod (Figure 9G) reaching as far as first pereopod; chela 0.6-0.8 times as long as carpus; dactylus 1.1-1.2 times longer than palm (Figure 9H). Third pereopod (Figure 9I) overreaching antennal scale by half to full length of propodus; dactylus somewhat compressed laterally, $0.15-0.20$ times as long as propodus, terminating in strong, curved unguis, flexor surface with 10-16 accessory spinules arranged in three or four irregular rows (Figure 9J); propodus with spinules arranged in two separate rows or double row on flexor surface (Figure 9J); carpus 075-0.90 times as long as propodus; merus unarmed; ischium usually unarmed, but rarely with one tiny spine. Fourth pereopod (Figure 9K) similar to third pereopod in structure; ischium always unarmed. Fifth pereopod (Figure 9L) generally similar to third and fourth; propodus with both lateral and mesial rows of spinules, each arranged into double row (spinules more numerous in lateral row than mesial row) (Figure 9M); propodus and carpus combined distinctly longer than merus and ischium combined; carpus $0.6-0.7$ times as long as propodus; ischium always unarmed. 
1806 T. Komai and S. Tsuchida

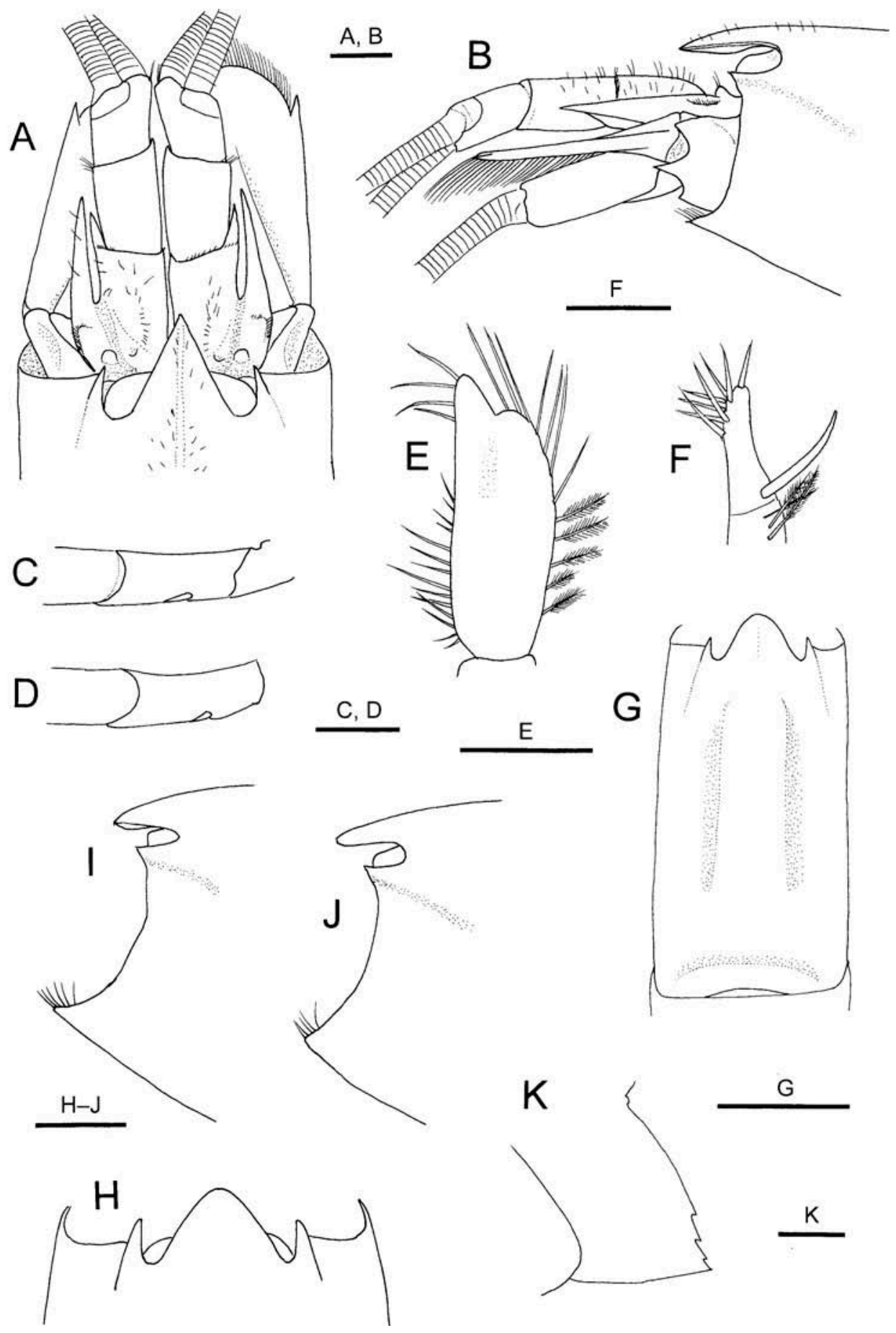


Appendices internae on second to fourth pereopods simple, on fifth pereopod normally developed, bearing terminal cluster of coupling hooks. Uropod (Figure 7E) with protopod (Figure $7 \mathrm{H}$ ) bearing subacute to acute posterolateral process; rami both overreaching posterior margin of telson; exopod slightly longer than endopod, with subequal posterolateral spines.

Males. Body less robust than in females. Rostrum (Figure 10A, B) acutely pointed, occasionally faintly carinate on dorsal midline. Carapace with sharp antennal tooth (Figure 10B); pterygostomial process narrower than in females, sharply pointed (Figure 10B). Pleon with fourth pleuron armed with small acute posteroventral tooth; fifth pleuron also with sharp posteroventral tooth and additional one to three small teeth or denticles on posterolateral margin. Antennal scale 1.8-1.9 times longer than wide; distolateral tooth more slender than in females, always clearly separated from lamella, acute (Figure 10A). Pereopods more slender than in females; ischium of third pereopod unarmed or armed with one spine, of fourth pereopod usually unarmed, but rarely armed with one spine (Figure 10C, D), and of fifth pereopod always unarmed. Endopod of first pleopod (Figure 10E) bilobed distally, mesial lobe prominent, with three or four long spiniform setae mesially, lateral lobe rather obsolete, also with row of spiniform setae extending onto lateral margin, proximal four or five of these setae bearing setules; mesial margin with row of spiniform setae. Appendix masculina of second pleopod (Figure 10F) stout, slightly longer than appendix interna, armed with about 10 spiniform setae distally. Posterolateral process of uropodal protopod acuminate.

Juveniles. Generally similar to adults, but body more compressed laterally. Rostrum rounded distally. Eyes each with minute tubercle on anterior surface dorsomesially.

Size

Males cl 4.8-11.9 mm; females cl 4.4-15.0 mm, ovigerous females cl 6.7-13.5 mm.

\section{Coloration in life}

Not known.

Figure 10. Chorocaris variabilis sp. nov. (A-F) Paratype, male (carapace length $8.3 \mathrm{~mm}$ ), JAMSTEC 066720-066722; (G-I, K) paratype, ovigerous female (carapace length $12.0 \mathrm{~mm}$ ), OUMNH.ZC.2014-01-015; (J) paratype, ovigerous female (carapace length $12.1 \mathrm{~mm}$ ), OUMNH.ZC.2014-01-015. (A) Anterior part of carapace and cephalic appendages, dorsal view; (B) same, lateral view; (C, D) ischia of third and fourth pereopods, lateral view; (E) endopod of left first pleopod, dorsal view; (F) appendices interna and masculina of left second pleopod, mesial view; $(\mathrm{G})$ carapace, dorsal view; (H) anterior part of carapace, dorsal view; (I, J) same, lateral view; (K), fifth pleonal pleuron, left side, lateral view. Scale bars: $5 \mathrm{~mm}$ for G; $2 \mathrm{~mm}$ for $\mathrm{H}-\mathrm{J} ; 1 \mathrm{~mm}$ for A-E, K; $0.5 \mathrm{~mm}$ for F. 


\section{Distribution}

Hydrothermal vents in southwestern Pacific. Manus Basin: South Su, 1305-1310 m; Solwara 1, 1570 m; PACMANUS, 1683-1684 m; Vienna Woods, 2480 m. North Fiji Basin: Mussel Hill, 1988 m. Vanuatu: Nifonea vent field, $1873 \mathrm{~m}$.

\section{Remarks}

The material of this new species came from three hydrothermal vent sites in the southwestern Pacific, i.e. Manus Basin, North Fiji Basin and Vanuatu. The specimens from the three locations are morphologically very similar. Of the four specimens used in the molecular phylogenetic analysis (see below), three specimens came from the Manus Basin, and one specimen was from the North Fiji Basin. The maximum genetic divergence among the four specimens is $1.8 \%$ (Table 1). Consequently it is reasonable to consider that these specimens represent a single species.

Chorocaris variabilis sp. nov. exhibits a substantial degree of variation in the shape of the rostrum and of the carapace teeth (see above). Males and non-spawning females differ from spawning females in having an acuminate rostrum with an occasionally faintly carinate dorsal surface (males), a sharply pointed antennal tooth and branchiostegal tooth on the carapace, and a clearly separated distolateral tooth on the antennal scale. Spawning females are characterized by the bluntly pointed rostrum, and antennal and branchiostegal teeth on the carapace.

Chorocaris variabilis sp. nov. is morphologically very similar to $C$. paulexa and C. vandoverae particularly in the prominent pterygostomial tooth on the carapace and the possession of 10-16 accessory spinules arranged in three or four rows on the flexor faces of the dactyli of the third to fifth pereopods. Nevertheless, C. variabilis differs from these two species in the possession of a conspicuous posteroventral tooth and additional denticles on the fifth pleonal pleuron and in the absence of setae on the anterior face of each eye. In $C$. paulexa and $C$. vandoverae, the posteroventral angle of the fifth pleonal pleuron is rounded or at most angular and the eye has several stiff setae on the anterior face. Furthermore, although somewhat variable in $C$. variabilis, the ventral surface of the rostrum is usually less convex than in $C$. paulexa and C. vandoverae.

Chorocaris vandoverae does not exhibit strong variation between males and nonspawning females on the one hand, and spawning females (Komai and Segonzac 2008). Hence, males and non-spawning females of this new species are readily distinguished from those of $C$. vandoverae by the acuminate rostrum and sharply pointed antennal and pterygostomial teeth on the carapace. In $C$. vandoverae, the rostrum is rounded distally, the pterygostomial tooth is more bluntly pointed, and the posterolateral angle of the fifth pleonal pleuron is at most subacute and devoid of additional denticles on the posterolateral margin. Furthermore, the armature of the appendix masculina of the second pleopod may be different between $C$. variabilis and C. vandoverae. In the new species, spiniform setae are restricted to the distal half of the appendix masculina, while similar spiniform setae form a row extending proximally beyond the midlength of the appendix masculina in $C$. vandoverae. With regard to spawning females, $C$. variabilis is distinguished from $C$. vandoverae in possessing a sharp posteroventral tooth on the fifth pleonal pleuron and a more sharply pointed protopod of the uropod. 


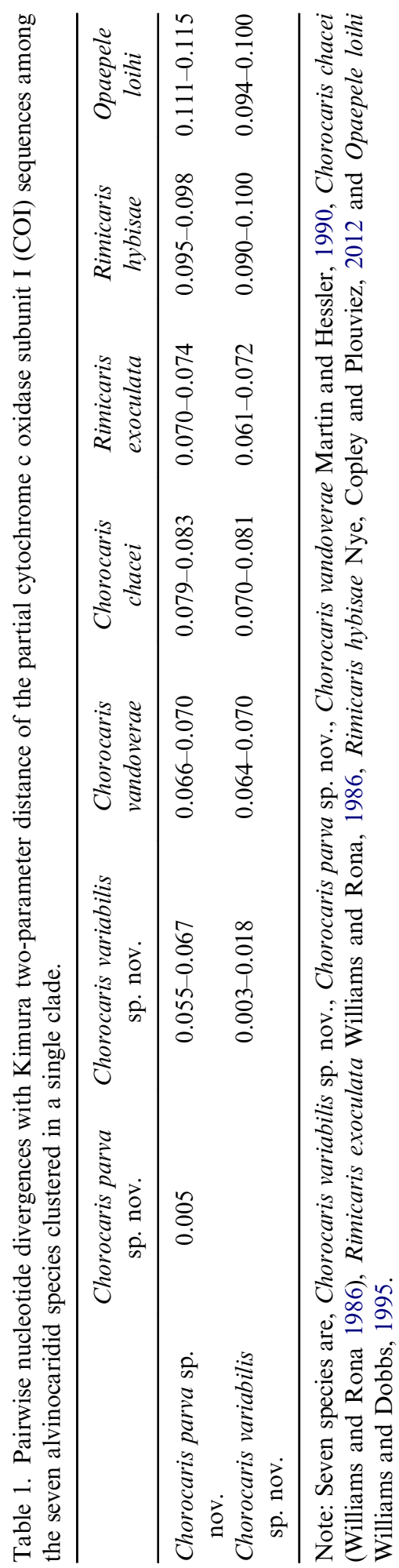


No information on the male is available for $C$. paulexa (cf. Martin and Shank 2005). Therefore variability between males and females in this species remains unknown. Nevertheless, the rostrum is proportionally narrower in $C$. variabilis than in C. paulexa (see Martin and Shank 2005; Komai and Segonzac 2008). In addition, the third to fifth pereopods seem to be more slender in this new species than in C. paulexa, but the significance of this character may be questionable because of intraspecific variation (as seen in other confamilial or congeneric species; see Komai and Segonzac 2003, 2004, 2008).

Records of $C$. vandoverae from hydrothermal vents on the North Fiji Basin (Desbruyères et al. 1994) and the Lau Basin (Desbruyères et al. 1994; Zelnio and Hourdez 2009) are referred to $C$. variabilis on the basis of the close morphological similarity between $C$. vandoverae and this new species, and their geographical distribution. Chorocaris sp. 2 reported from the Manus Basin by Zelnio et al. (2010) corresponds to $C$. variabilis. Consequently the occurrence of $C$. vandoverae outside the Mariana Back Arc Basin is unconfirmed.

Etymology. From the Latin variabilis (= variable) in reference to the substantial morphological variation seen in this new species.

\section{Manuscaris gen. nov.}

Type species

Manuscaris acuminatus sp. nov.

\section{Composition}

Monotypic

\section{Diagnosis}

Rostrum narrowly triangular in dorsal view, slightly overreaching distal margin of first segment of antennular peduncle; dorsal margin sharply carinate, armed with row of conspicuous teeth, posteriormost tooth located just posterior to rostral base; ventral margin nearly flat, with minute denticle subterminally. Carapace with low, blunt postrostral carina not extending to midlength; antennal tooth acuminate, with small lobe ventromesial to its base; pterygostomial tooth strong, acuminate; anterior part of branchial region not inflated. Third to fifth pleonal pleura at least with posteroventral tooth. Telson with dorsolateral spines in linear row; posterior margin convex, with row of plumose setae flanked by two pairs of lateral spines. Eyes fused, though shallow median notch evident; anterior surface of each eye flat, unarmed. Antennular stylocerite well separated from first peduncular segment. Antenna not forming operculate structure (see Martin and Hessler 1990); antennal scale with sharp distolateral tooth clearly separated from lamella; no transverse suture extending mesially from base of distolateral tooth. First maxilliped with rudimentary bud of exopodal flagellum. First pereopod with well-developed grooming apparatus on carpus consisting of patch of setae and one small spine. Second pereopod with 
spine on ischium. Third pereopod shorter than fifth pereopod; dactyli with accessory spinules on flexor margins arranged in two rows; meri of third and fifth pereopods unarmed; ischia of third pereopods with two spines. No strap-like epipods on third maxilliped to fourth pereopods. Appendix interna of fourth pleopod without terminal cluster of coupling hooks. Uropodal exopod with one spine just mesial to sharp posterolateral tooth; protopod terminating posterolaterally in sharp tooth.

\section{Remarks}

Manuscaris gen. nov. appears to be close to a group of genera that includes Alvinocaridinides, Shinkaicaris, Opaepele, Chorocaris and Rimicaris based on sharing the following apparently apomorphic characters: rostrum more or less reduced in length with reduced ventral limb; eyes broadly fused with shallow median notch, each anterior surface rather flat and unarmed; dactyli of third to fifth pereopods each with accessory spinules arranged in two or more rows; and meri of third to fifth pereopods devoid of spines. Nevertheless, the new genus is excluded from this group by the dorsolateral spines on the telson arranged in a linear row and the presence of spines on the ischia on the third and fourth pereopods, which are presumably plesiomorphic characters (cf. Komai and Segonzac, 2005).

\section{Etymology}

A combination of the name of the type locality (Manus Basin) and the Greek caris (= shrimp). Gender: masculine.

\section{Manuscaris acuminatus sp. nov.}

(Figures 11-14)

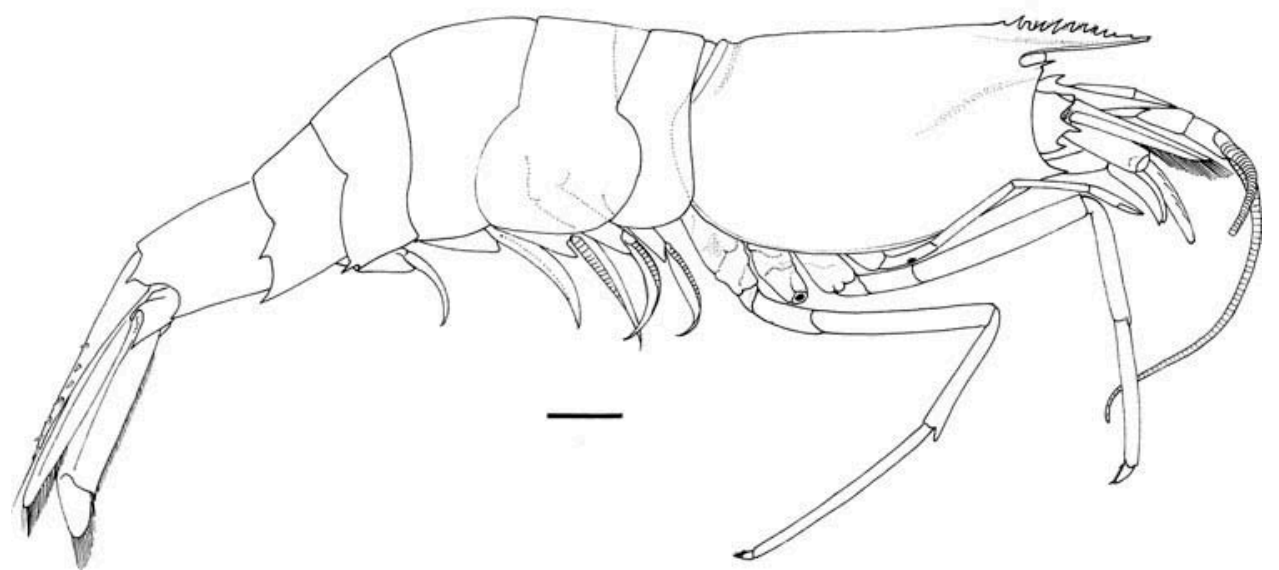

Figure 11. Manuscaris acuminatus gen. et sp. nov., holotype, male (carapace length $8.4 \mathrm{~mm}$ ), CBM-ZC 11955, entire animal in lateral view. Scale bar: $2 \mathrm{~mm}$. 


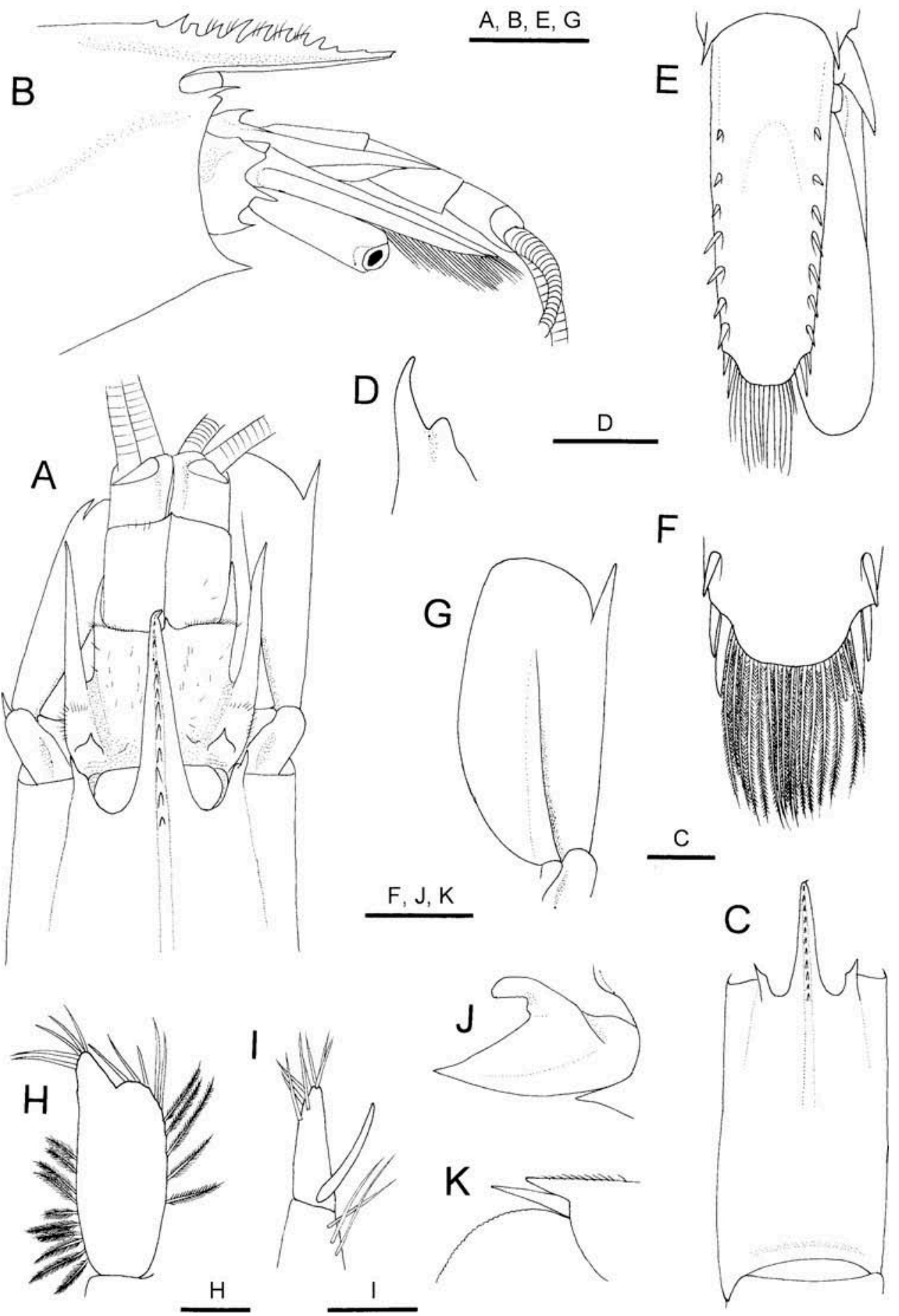



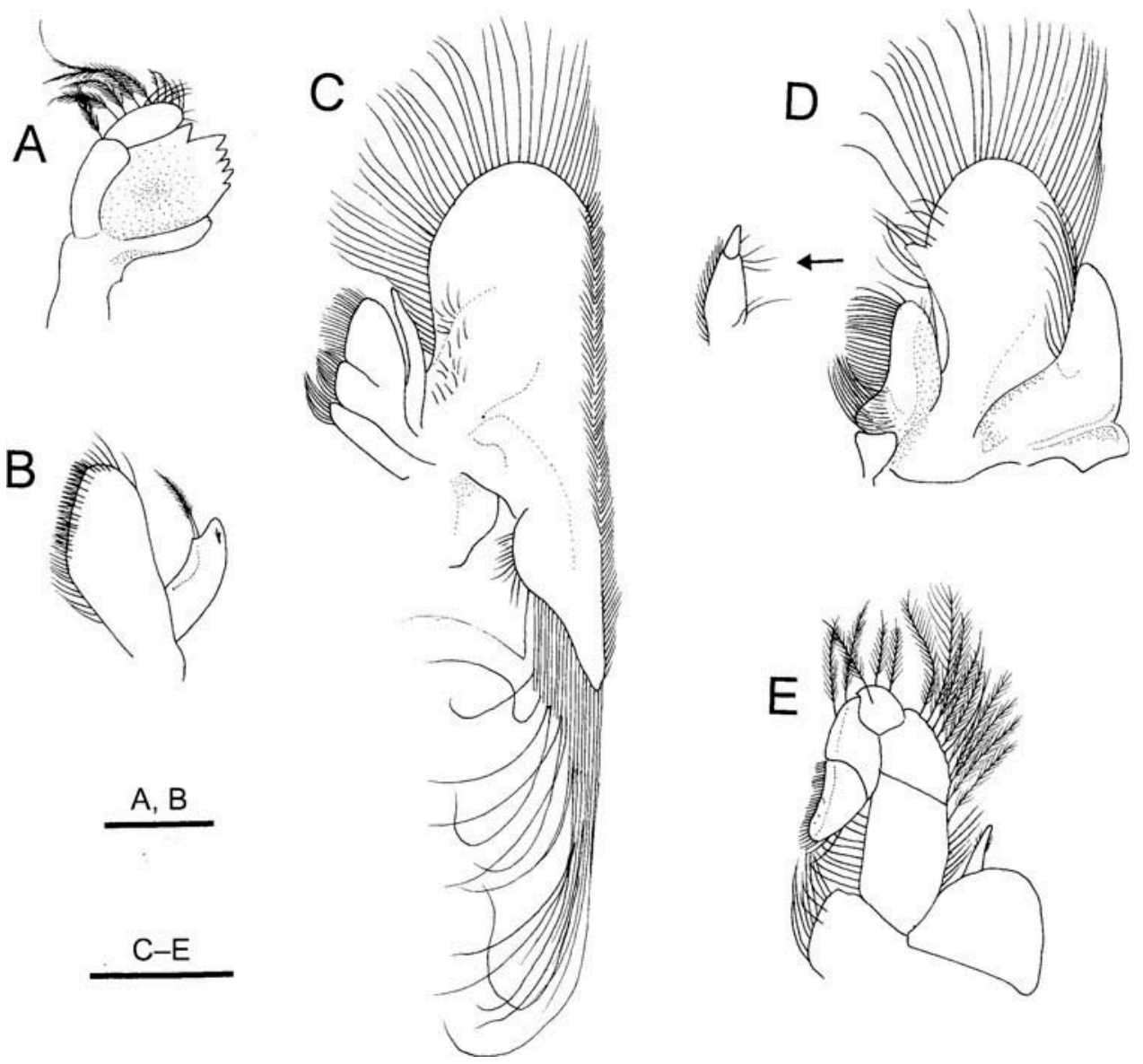

Figure 13. Manuscaris acuminatus gen. et . sp. nov., holotype, male (carapace length $8.4 \mathrm{~mm}$ ), CBM-ZC 11955. Left mouthparts. (A) Mandible, inner view; (B) maxillule, outer view (coxal endite missing); (C) maxilla, outer view; (D) first maxilliped, outer view; inset, endopod, inner view; (E) left second maxilliped, outer view. Scale bars: $1 \mathrm{~mm}$ for C-E; $0.5 \mathrm{~m}$ for A, B.

\section{Type material}

Holotype. Wave Mercury 2007 Campaign, dive 35, South Su, Manus Basin, $3^{\circ} 08.09^{\prime} \mathrm{N}, 152^{\circ} 10.5^{\prime} \mathrm{E}, 1310 \mathrm{~m}, 15$ April 2007, male (cl $8.4 \mathrm{~mm}$ ), CBM-ZC 11,955 .

Figure 12. Manuscaris acuminatus gen. et sp. nov., holotype, male (carapace length $8.4 \mathrm{~mm}$ ), CBM-ZC 11955. (A) Anterior part of carapace and cephalic appendages, dorsal view; (B) same, lateral view; (C) carapace, dorsal view; (D) left antennal tooth on carapace, dorsal view; (E) telson and right uropod, dorsal view (marginal setae on uropod omitted); (F) posterior part of telson, dorsal view; $(\mathrm{G})$ right antennal scale, dorsal view (setae omitted); $(\mathrm{H})$ endopod of left first pleopod, dorsal view; (I) appendices interna and masculina of left second pleopod, mesial view; (J) protopod of right uropod, dorsolateral view; (K) posterolateral part of left uropodal exopod, dorsal view. Scale bars: Scale bars: $2 \mathrm{~mm}$ for A-C, E, G; $1 \mathrm{~mm}$ for F, J, K; $0.5 \mathrm{~mm}$ for D, H, I. 


\section{Description of holotype}

Body integument fairly thin, almost glabrous on surface.

Rostrum (Figure 12A, B) narrowly triangular in dorsal view, slightly overreaching distal margin of first segment of antennular peduncle, about 0.4 times as long as carapace; dorsal margin carinate, with 11 unequal teeth, posteriormost and distal two teeth distinctly smaller than other teeth, posteriormost tooth located slightly posterior to orbital margin; sparse short setae on proximal five teeth; ventral surface nearly flat (non-carinate), with minute denticle subterminally; ventrolateral carina sharply defined, merging into orbital margin. Carapace (Figures 11, 12C) with low, blunt postrostral carina not extending to midlength, so dorsal margin in lateral view nearly straight; antennal tooth slender, acuminate, with small blunt lobe ventromesial to its base; pterygostomial tooth strong, reaching slightly beyond tip of antennal tooth; anterior part of branchial region not inflated.

Pleon as figured (Figure 11). Third pleuron with one small posteroventral tooth; fourth pleuron with one rather strong posteroventral tooth and one much smaller additional tooth anterior to it on ventral margin; fifth pleuron with strong posteroventral tooth and one additional conspicuous tooth on posterolateral margin. Sixth pleomere 1.6 times as long as fifth pleomere and 1.2 times longer than high, with strong, acute posteroventral tooth; posterolateral process terminating in sharp tooth. Telson (Figure 12E) 3.1 times longer than anterior width, armed with seven dorsolateral spines arranged in linear row on either side and two pairs of posterolateral spines; posterior margin with 14 long plumose setae (Figure 12F).

Eyes (Figure 12B) broadly fused, but with shallow median groove, closely approximated to ventral face of rostrum; each anterior surface nearly flat, unarmed.

Antennular peduncle (Figure 12A, B) reaching distal margin of antennal scale. First segment with forwardly directed, spiniform proximolateral tubercle; distolateral tooth long, slender, reaching beyond midlength of second segment, distomesial margin with small tooth; stylocerite slender, slightly diverging, reaching nearly to distal margin of second segment. Second segment 1.6 times as long as wide, with small distomesial tooth.

Antenna (Figure 12A, B) with basicerite bearing a slender ventrolateral tooth and a sharp ventral tooth. Carpocerite moderately stout, slightly overreaching midlength of antennal scale. Antennal scale about 0.5 times as long as carapace and 2.2 times longer than wide; lateral margin nearly straight; distolateral tooth slender, clearly separated from distal lamella by rather narrow, deep notch, tooth reaching distal margin of lamella; no suture mesial to base of distolateral tooth; dorsal carina distinct, slightly diverging from lateral margin; distal lamella rounded.

Figure 14. Manuscaris acuminatus gen. et . sp. nov., holotype, male (carapace length $8.4 \mathrm{~mm}$ ), CBM-ZC 11955. (A) Left third maxilliped, lateral view; (B) same, epipod, dorsal view; (C) left first pereopod, lateral view; (D) same, chela, inner (flexor) view; (E) same, carpus, mesial view, showing grooming apparatus; (F) left second pereopod, lateral view; $(G)$ same, chela, extensor view; $(\mathrm{H})$ left third pereopod, lateral view; (I) dactylus and distal part of propodus of right third pereopod, lateral view; (J) dactylus of right third pereopod, flexor view; (K) distal part of propodus of right third pereopod, flexor view; (L) right fifth pereopod, lateral view; (M) same, dactylus and distal part of propodus, lateral view; $(\mathrm{N})$ same, flexor view. Scale bars: $2 \mathrm{~mm}$ for A, C, F, H, L; $1 \mathrm{~mm}$ for B; $0.5 \mathrm{~mm}$ for D, E, I-K, M, N. 
Mandible (Figure 13A) with terminally blunt molar process; incisor process with six triangular teeth mesially. Maxillule (Figure 13B) endopod slightly bilobed, distomesial lobe with one apical plumose seta, distolateral lobe with two minute submarginal setae. Maxilla (Figure 13C) with scaphognathite moderately broad, with some short facial setae restricted to mesial part. First maxilliped (Figure 13D) with rudimentary bud of flagellum on mesial margin of broad exopod; endopod (Figure 13D, inset) short, bi-articulated. Second maxilliped (Figure 13E) with relatively stout endopod; epipod subsemicircular, bearing slender, rod-like, non-lamellate podobranch.

Third maxilliped (Figure 14A) typical of alvinocaridid, slightly overreaching distal margin of antennal scale. Distal two segments combined gently arcuate, ultimate segment tapering distally, trigonal in cross-section, about 1.2 times as long as penultimate segment (= carpus). Antepenultimate segment with slender ventrolateral distal spine and prominent tuft of setae on dorsomesial proximal part. Epipod widened distally, slightly bilobed, lacking strap-like process (Figure 14B).

First pereopod (Figure 14C) slightly falling short of distal margin of antennal scale; dactylus 5.5 times longer than palm; chela (Figure 14D) slender, 2.8 times longer than wide; carpus (Figure 14E) relatively slender, with blunt ventrodistal tooth; mesial surface ventrally with grooming apparatus consisting of patch of short stiff setae and one small spine proximal to patch of setae (Figure 14E). Second pereopod (Figure 14F) not reaching distal margin of antennal scale; chela 0.8 times as long as carpus; dactylus subequal in length to palm (Figure 14G); ischium with one spine laterally. Third pereopod (Figure 14H) overreaching antennal scale by full length of dactylus and propodus combined; dactylus (Figure 14I, J) 0.2 times as long as propodus, terminating in strong, clearly demarcated unguis, bearing four pairs of accessory spinules on flexor surface; propodus (Figure 14K) with two rows of slender spinules on flexor surface in distal half; carpus 0.9 times as long as propodus; merus 6.6 times longer than wide; ischium with two spines ventrolaterally. Fourth pereopod missing. Fifth pereopod (Figure 14L) longer than third pereopod, overreaching antennal scale by about 0.8 length of propodus; dactylus (Figure 14M, N) with 12 accessory spinules arranged in two or three rows on flexor surface (Figure $14 \mathrm{~N}$ ); propodus with three or four irregular rows of slender spines or spiniform setae on flexor surface (Figure 14N); carpus 1.6 times as long as propodus; merus about 7.3 times longer than wide; ischium unarmed.

Endopod of male first pleopod (Figure 12H) with inner lobe produced, far exceeding outer lobe, bearing cluster of five spiniform setae distally; outer lobe broadly rounded, with five spiniform setae; lateral margin slightly convex, with five stout plumose setae; mesial margin faintly sinuous, with 10 stout plumose setae. Appendices internae of second to fifth pleopods normally developed, with terminal cluster of coupling hooks, while that on fifth pleopod lacking coupling hooks. Appendix masculina on second pleopod (Figure 12I) tapering distally, slightly longer than appendix interna, armed with about seven spiniform setae distally. Uropodal rami (Figure 12E) both overreaching posterior margin of telson; exopod with one slender spine just mesial to sharp posterolateral tooth (Figure 12K).

\section{Coloration in life}

Not known. 


\section{Distribution}

Known only from the type locality, South Su hydrothermal vent field, Manus Basin, $1310 \mathrm{~m}$ depth.

Etymology

From the Latin, acuminatus (= sharp), in reference to the sharp stylocerite and proximolateral tubercle on the first segment of the antennular peduncle.

Genus Alvinocaris Williams and Chace, 1982

Alvinocaris komaii Zelnio and Hourdez, 2009

Alvinocaris komaii Zelnio and Hourdez, 2009: 55, figs. 1-6.

\section{Material examined}

Non-type. Lau Basin. BIOLAU, BL 08, site Vailili, 23ำ13' S, 176 $38^{\prime}$ W, 1740 m, 18 May 1989, slurp gun, 1 male (cl 12.2 mm), MNHN; BL 10, same site, 22 May 1989, 1 female (cl 15.2 mm), CBM-ZC 11,956. North Fiji Basin. STARMER II, RV Kaiyo, dive 19, site White Lady, 1850' S, 173²9' E, 2750 m, July 1989, 1 female (cl 14.6 mm), MNHN. Vanuatu. RV Sonne, SO229-061-N202, Nifonea vent field, $18^{\circ} 07.735^{\prime} \mathrm{S}, 169^{\circ}$ $31.018^{\prime}$ E, 1871 m, 19 July 2013, 1 female (cl 19.5 mm), CBM-ZC 12,483.

\section{Supplemental description}

Rostrum (Figure 15A-C) slender, terminating acutely, reaching or overreaching distal margin of first segment of antennular peduncle; dorsal margin sharply carinate, armed with row of teeth becoming larger posteriorly and extending beyond midlength of carapace (five postrostral teeth present); ventral ridge well developed, armed with one or more teeth; lateral carina conspicuous. Carapace (Figure 15A, B) with distinct postrostral carina extending beyond midlength; dorsal margin of carapace in lateral view gently arcuate, with peak at posteriormost tooth of dorsal rostral series; no longitudinal depression on either side of midline even in spawning females; antennal tooth acuminate; pterygostomial tooth strong, acuminate; anterior part of branchial region not strongly inflated; dorsal organ absent.

Third pleomere (Figure 15D) armed with one or more denticles posteroventrally on pleuron; fourth pleuron armed with sharp posteroventral tooth and additional denticles or teeth on posterolateral and/or ventral margins; fifth pleuron with posteroventral tooth and additional teeth on posterolateral margin. Telson (Figure 15E) with dorsolateral spines in linear row; posterior margin distinctly bilobed, with row of spines (Figure 15F).

Eyes fused, though distinct median notch present; anterior surface rounded, unarmed (Figure 15C).

Antennular stylocerite slender, narrowly separated from first peduncular segment (Figure 15C). Antenna not forming operculate structure; antennal scale with sharp distolateral tooth clearly separated from lamella; no transverse suture extending mesially from base of distolateral tooth (Figure 15C). 


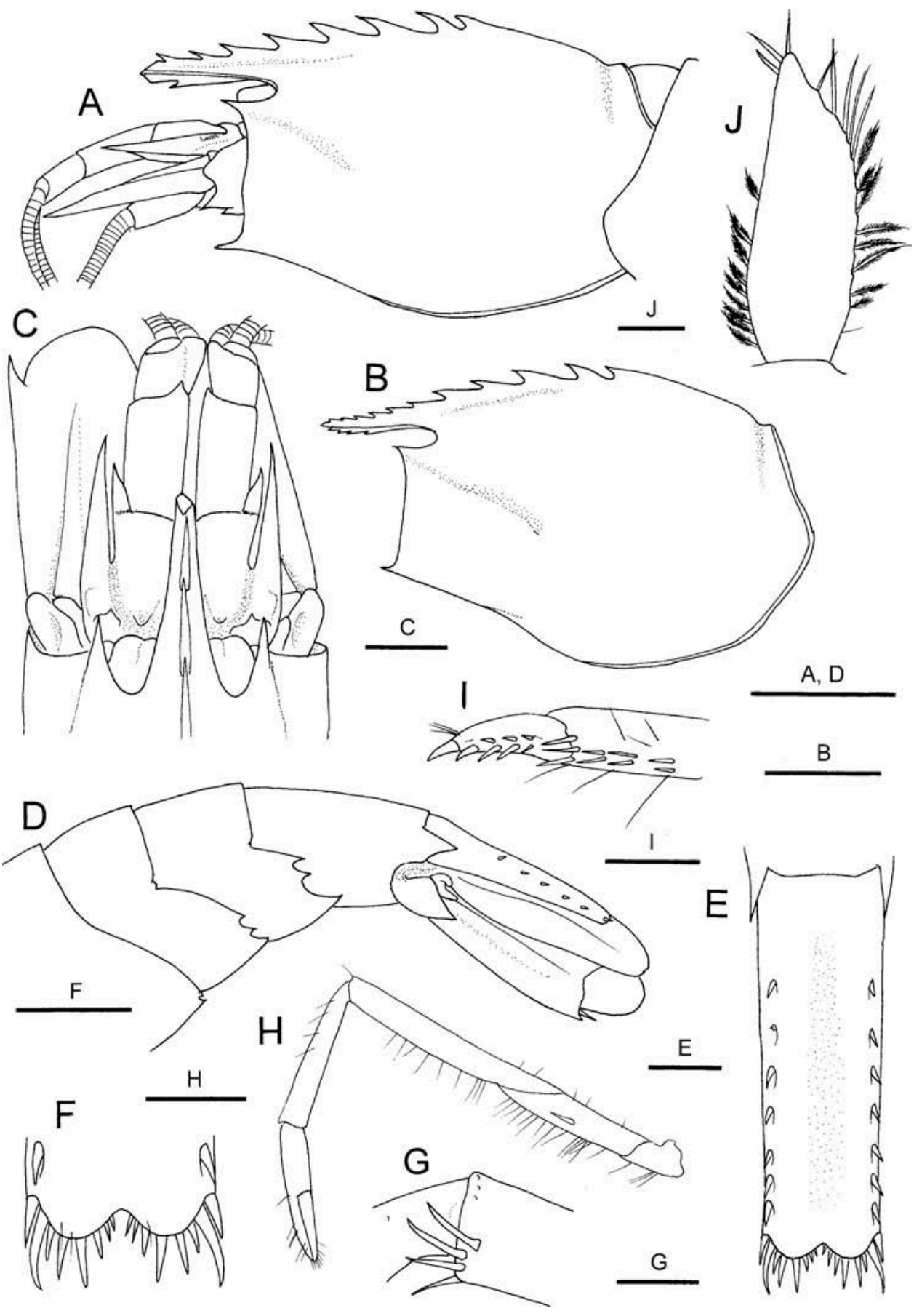


First maxilliped without rudimentary bud of exopod. Third maxilliped with two or more slender spines at ventrodistal margin of antepenultimate segment (Figure 15G).

First pereopod with short grooming setae on flexor surface of palm; carpus with well-developed grooming apparatus consisting of patch of short setae and one or two spinules proximal to setal patch. Second pereopod (Figure 15H) with one spine on ischium. Third to fifth pereopods increasing in length posteriorly; dactyli each with seven or eight accessory spinules arranged in two longitudinal rows on flexor surface (Figure 15I); meri of third and fourth pereopods each with one to three spines on lateral faces, that of fifth pereopod unarmed; ischia of third and fourth pereopods each with one or two spines, that of fifth pereopod unarmed. No strap-like epipods on third maxilliped or first to fourth pereopods.

Endopod of male first pleopod not bilobed distally, with three stiff setae distomesially; lateral margin with six or seven stiff setae in distal 0.3. Appendix interna of fourth pleopods without terminal cluster of coupling hooks. Uropodal exopod with one spine just mesial to base of posterolateral tooth; protopod sharply pointed posterolaterally.

\section{Distribution}

Lau Basin (Zelnio and Hourdez 2009; this study), 1740-2700 m depths; North Fiji Basin, $2750 \mathrm{~m}$ depth (new record); and Vanuatu, Nifonea vent field, $1871 \mathrm{~m}$ depth (new record).

\section{Remarks}

The present specimens are consistent with the original description of Alvinocaris komaii in every diagnostic aspect.

Molecular phylogenetic analysis based on $600 \mathrm{bp}$ of the mitochondrial COI nucleotide by Zelnio and Hourdez (2009) suggested that A. komaii was clustered with the Opaepele/Chorocaris/Rimicaris clade, although the bootstrap support was very low (39.7\%). As described previously by Zelnio and Hourdez (2009), A. komaii differs from other species of Alvinocaris in the accessory spinules on the dactyli of the third to fifth pereopods arranged in two or more rows and the unarmed anterior face of each eye. These characters, and the molecular analysis presented herein support the closer relationship of the species to a group including Alvinocaridinides, Chorocaris, Opaepele, Shinkaicaris and Rimicaris. Furthermore, A. komaii has two unique characters within the family, namely, the distinctly bilobed posterior margin of the telson

Figure 15. Alvinocaris komaii Zelnio and Hourdez,, 2009. (A, C, D, G-I) Male (carapace length $12.2 \mathrm{~mm}$ ), MNHN (rostrum damaged); (B, E, F) female (carapace length $14.6 \mathrm{~mm}$ ), MNHN. (A) Carapace and cephalic appendages, lateral view; (B) carapace, lateral view; (C) anterior part of carapace and cephalic appendages, dorsal view; (D) posterior part of pleon, lateral view (posterior part of telson broken off); (E) telson, dorsal view; (F) posterior part of telson, dorsal view; (G) distal part of antepenultimate segment of left third maxilliped, lateral view; $(\mathrm{H})$ left second pereopod, lateral view; (I) same, dactylus and distal part of propodus, flexor view. Scale bars: $5 \mathrm{~mm}$ for A, B, D; $2 \mathrm{~mm}$ for C, E, H; $0.5 \mathrm{~mm}$ for G, I, J. 
and the multiple spines on the ventrodistal margin of the antepenultimate segment of the third maxilliped. Future study may potentially warrant the establishment of a separate genus for A. komaii.

\section{Genetic divergence of the two new species of Chorocaris}

The ML tree inferred from partial COI sequences (460 bp) for 18 identified species (including the two new species referred to Chorocaris) and two unidentified species of the Alvinocarididae is shown in Figure 16. At present, COI sequences are not

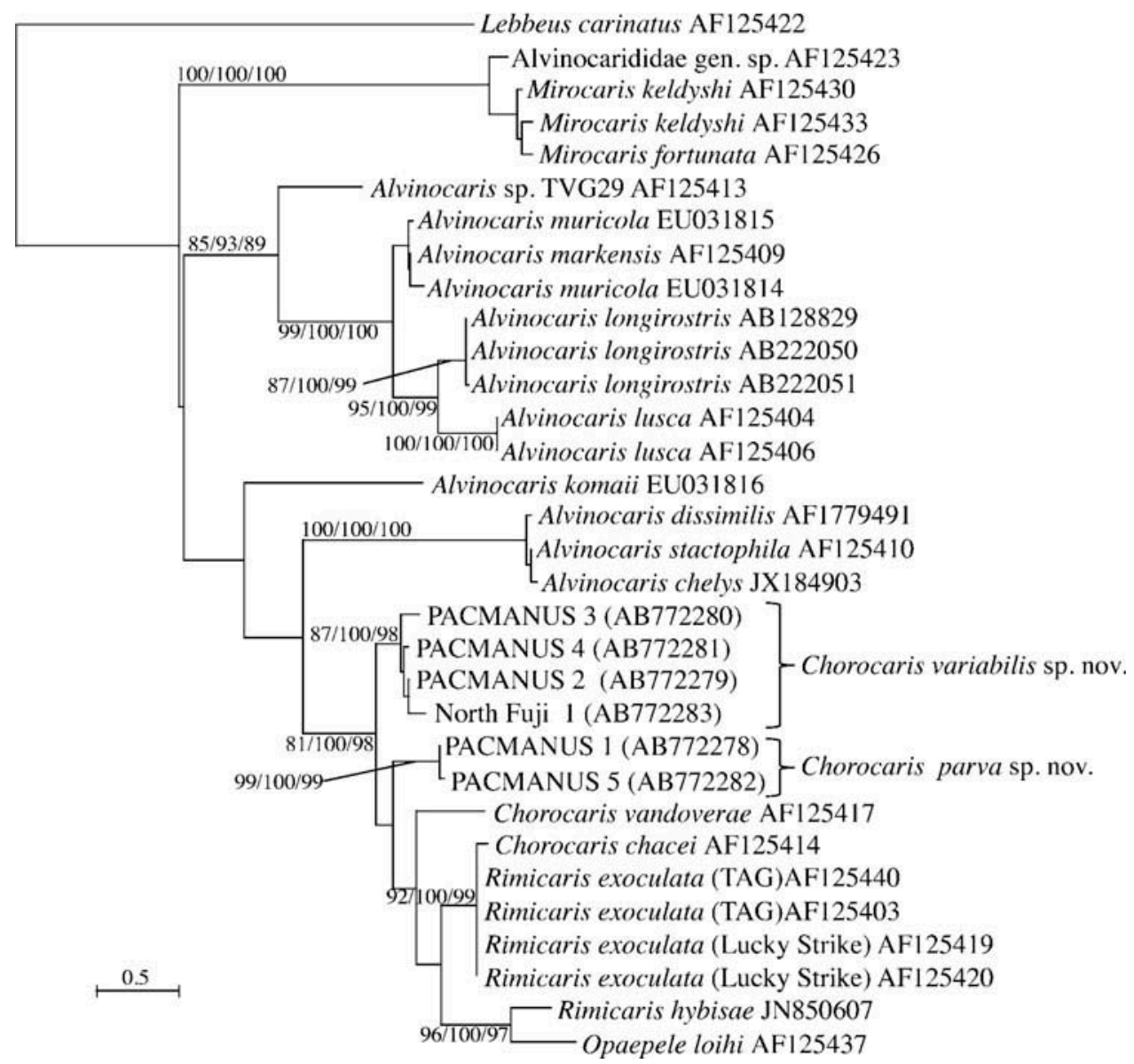

Figure 16. Molecular tree of the Alvinocarididae based on partial cytochrome c oxidase subunit I (COI) sequences (460 bp), constructed by the maximum likelihood (ML) method. Lebbeus laurentae Wicksten, 2010 (registered as L. carinatus in GenBank) used as an outgroup. Bootstrap values greater than $70 \%$ are given for branches with 500 replicate sampling in the sequence of ML, maximum parsimony (MP) and neighbour-joining (NJ). Note that Mirocaris keldyshi Vereshchaka, 1997 is a junior synonym of Mirocaris fortunata (Martin and Christiansen, 1995). 
available for the following 13 formally described species: Alvinocaridinides formosa Komai and Chan, 2010, Alvinocaris alexander Ahyong, 2009, Alvinocaris brevitelsonis Kikuchi and Hashimoto, 2000, Alvinocaris methanophila Komai, Shank and Van Dover, 2005, Alvinocaris niwa Webber, 2004, Alvinocaris williamsi Shank and Martin, 2003, Chorocaris paulexa, Chorocaris susannae, Manuscaris acuminatus gen. et sp. nov., Mirocaris indica Komai et al. (2006), Nautilocaris saintlaurentae Komai and Segonzac, 2004, Rimicaris kairei Watabe and Hashimoto, 2002, and Shinkaicaris luerokolos (Kikuchi and Hashimoto, 2000).

The two new species of Chorocaris are clustered in a clade consisting of C. chacei, C. vandoverae, Opepele loihi, Rimicaris exoculata and Rimicaris hybisae with relatively high bootstrap support (88\%, 93\% and $100 \%$ in ML, MP and NJ, respectively) (Figure 16). The relationship among these species could not be fully resolved, because some inner branches have weak bootstrap support (less than 70\%; e.g. the position of $C$. parva sp. nov., $C$. vandoverae and $C$. variabilis sp. nov.). The monophyly of Chorocaris is not supported, with the two Rimicaris species and O. loihi subordinated within Chorocaris.

Interspecific divergence among these seven species is summarized in Table 1. The minimum divergence is seen between $C$. variabilis sp. nov. and $C$. parva sp. nov. (5.5$6.7 \%$ ), whereas the maximum divergence is seen between $C$. variabilis sp. nov. and O. loihi (11.0-11.5\%). Previous studies on decapod crustaceans [e.g. Jones and Macpherson 2007 (Anomura: Munidopsidae: Munidopsis); Cabezas et al. 2009 (Anomura: Munididae: Munida and allied genera); Tsoi et al. 2011 (Achelata: Palinuridae: Linuparus); Chang et al. 2014 (Astacidea: Nephropidae: Thaumastocheles)] have shown that COI divergence of more than $10 \%$ is indicative of species level differentiation, although lower divergence $(>4.0 \%)$ could also be of specific significance [(e.g. Davie et al. 2010 (Brachyura: Micytlidae: Mictylis); Yang et al. 2010 (Caridea: Pandalidae: Heterocarpus)]. Together with the morphological evidence, we consider that full species status is warranted for the two new taxa described in this study.

Four specimens of $C$. variabilis sp. nov. (three from the Manus Basin and one from the North Fiji Basin) are clustered with well-supported bootstrap value (93\%, $96 \%$ and $100 \%$ in ML, MP and NJ, respectively). The intraspecific divergence in the four specimens is $0.3-1.8 \%$, and there is little doubt that they belong to the same species.

\section{Acknowledgements}

We thank Cindy L. Van Dover and Patrick Collins (Duke University Marine Laboratory) and Verena Tunnicliffe (Biology and Earth/Ocean Sciences, University of Victoria) for making the valuable material available for study, and Sammy De Grave and Tin-Yam Chan for critically reading drafts of the manuscript and offering valuable comments for improvements. Critical reviews by two anonymous referees and the subject editor (Dr Louise Allcock) are also deeply appreciated. The Wave Mercury 2007 material was collected with support from Nautilus Minerals on behalf of the people of Papua New Guinea. We also thank the chief scientist of YK06-13, Dr Yohey Suzuki (The University of Tokyo), the captain and crew of RV Yokosuka, and the operation teams of the DS Shinkai 6500 for their skilful collection of specimens. 


\section{References}

Ahyong ST. 2009. New species and new records of hydrothermal vent shrimps from New Zealand (Caridea: alvinocarididae, Hippolytidae). Crustaceana. 82:775-794.

Cabezas P, Macpherson E, Machordom A. 2009. Morphological and molecular description of new species of squat lobster (Crustacea: decapoda: Galatheidae) from the Solomon and Fiji Islands (South-West Pacific). Zool J Linn Soc. 156:465-493.

Chang SC, Chan TY, Ahyong ST. 2014. Two new species of the rare lobster genus Thaumastocheles Wood-Mason, 1874 (Reptantia: nephropidae) discovered from recent deep-sea expeditions in the Indo-West Pacific. J Crust Biol. 34:107-122.

Christoffersen ML. 1986. Phylogenetic relationships between Oplophoridae, Atyidae, Pasiphaeidae, Alvinocarididae fam. n., Bresiliidae, Psalidopodidae and Disciadidae (Crustacea Caridea Atyoidea). Bolm Zool, Univ S Paulo. 10:273-281.

Davie PJF, Shih HT, Chan BKK. 2010. A new species of Mictylis (Decapoda, Brachyura, Mictylidae) from the Ryukyu Islands, Japan.

Desbruyères D, Alayse-Danet AM, Ohta S, Antoine T. 1994. Deep-sea hydrothermal communities in Southwestern Pacific back-arc basins (the North Fiji and Lau Basins): composition, microdistribution and food web. Mar Geol. 116:227-242.

Embley RW, Chadwick CWW, Baker ET, Butterfield DA, Resing JA, De Ronde CEJ, Tunnicliffe V, Lupton JE, Juniper K, Rubin KH, et al. 2006. Long term eruptive activity at a submarine arc volcano. Nature. 441:494-497.

Folmer O, Black M, Hoeh W, Lutz R, Vrijenhoek R. 1994. DNA primers for amplification of mitochondrial cytochrome c oxidase subunit I from diverse metazoan invertebrates. Mol Mar Biol Biotechnol. 3:294-299.

Guindon S, Dufayard F, Lefort V, Anisimova M, Hordijk W, Gascuel O. 2010. New algorithms and methods to estimate maximum-likelihood phylogenies: assessing the performance of PhyML 3.0. Syst Biol. 59:307-321.

Jones W, Macpherson E. 2007. Molecular phylogeny of the east Pacific squat lobsters of the genus Munidopsis (Decapoda: galatheidae) with the descriptions of seven new species. J Crust Biol. 27:477-501.

Kikuchi T, Hashimoto J. 2000. Two new caridean shrimps of the family Alvinocarididae (Crustacea, Decapoda) from a hydrothermal field at the Minami-Ensei Knoll in the Mid-Okinawa Trough, Japan. Sp Div. 5:135-148.

Kimura M. 1980. A simple method for estimating evolutionary rates of base substitutions through comparative studies of nucleotide sequences. J Mol Evol. 16:111-120.

Komai T, Chan TY. 2010. Two new species of alvinocaridid shrimps (Crustacea: decapoda: Caridea) from hydrothermally influenced field off northeastern Taiwan. Zootaxa. 2372:15-32.

Komai T, Giere O, Segonzac M. 2007. New record of alvinocaridid shrimps (Crustacea: decapoda: Caridea) from hydrothermal vent fields on the southern Mid-Atlantic Ridge, including a new species of the genus Opaepele. Spec Div. 12:237-253.

Komai T, Martin JW, Zala K, Tsuchida S, Hashimoto J. 2006. A new species of Mirocaris (Crustacea: decapoda: Caridea: alvinocarididae) associated with hydrothermal vents at Kairei Field, Central Indian Ridge. Sci Mar. 70:109-119.

Komai T, Segonzac M. 2003. A review of the hydrothermal vent shrimp genus Mirocaris, redescription of $M$. fortunata (Martin \& Christiansen), and reassessment of the taxonomic status of the family Alvinocarididae (Crustacea: decapoda: Caridea). Cah Biol Mar. 44:199-215.

Komai T, Segonzac M. 2004. A new genus and species of alvinocaridid shrimp (Crustacea: decapoda: Caridea) from hydrothermal vents on the North Fiji and Lau Basins, southwestern Pacific. J Mar Biol Assoc UK. 84:1179-1188. 
Komai T, Segonzac M. 2005. A revision of the genus Alvinocaris Williams and Chace (Crustacea: decapoda: Caridea: alvinocarididae), with descriptions of a new genus and a new species of Alvinocaris. J Nat Hist. 39:1111-1175.

Komai T, Segonzac M. 2008. Taxonomic review of the hydrothermal vent shrimp genera Rimicaris Williams \& Rona and Chorocaris Martin \& Hessler (Crustacea: decapoda: Caridea: alvinocarididae). J Shell Res. 27:21-41.

Komai T, Shank TM, Van Dover CL. 2005. A new species of Alvinocaris (Crustacea: decapoda: Caridea: alvinocarididae) and new record of $A$. muricola from methane seeps on the Blake Ridge Diapir, Northwestern Atlantic. Zootaxa. 1019:27-42.

Lunina AA, Vereshchaka AL. 2010. A new vent shrimp (Crustacea: decapoda: alvinocarididae) from the Mid-Atlantic Ridge. Zootaxa. 2372:69-74.

Lunina AA, Vereshchaka AL. 2014. Distribution of hydrothermal alvinocaridid shrimps: effect of geomorphology and specialization to extreme biotopes. PLoS ONE. 9:e92802.

Martin JW, Christiansen JC. 1995. A new species of the shrimp genus Chorocaris Martin \& Hessler, 1990 (Crustacea: Decapoda: Bresiliidae) from hydrothermal vent fields along Mid-Atlantic Ridge. Proc Biol Soc Wash. 108:220-227.

Martin JW, Haney TA. 2005. Decapod crustaceans from hydrothermal vents and cold seeps: a review through 2005. Zool J Linn Soc. 145:445-522.

Martin JW, Hessler RR. 1990. Chorocaris vandoverae, a new genus and species of hydrothermal vent shrimp (Crustacea, Decapoda, Bresiliidae) from the Western Pacific. Contr Sci. 417:1-11.

Martin JW, Shank TM. 2005. A new species of the shrimp genus Chorocaris (Decapoda: caridea: alvinocarididae) from hydrothermal vents in the eastern Pacific Ocean. Proc Biol Soc Wash. 118:183-198.

Nye V, Copley J, Plouviez S. 2012. A new species of Rimicaris (Crustacea: decapoda: caridea: alvinocarididae) from hydrothermal vent fields on the Mid-Cayman Spreading Centre, Caribbean. J Mar Biol Assoc UK. 92:1057-1072.

Shank TM. 1999. Miocene Radiation of deep-sea hydrothermal vent shrimp (Caridea: bresiliidae): evidence from mitochondrial cytochrome oxidase subunit I. Mol Phylogenet Evol. 13:244-254.

Shank TM, Martin JW. 2003. A new caridean shrimp of the family Alvinocarididae from thermal vents at Menez Gwen on the Mid-Atlantic Ridge. Proc Biol Soc Wash. 116:158-167.

Swofford DL. 2002. PAUP*. Phylogenetic Analysis Using Parsimony (*and Other Methods). Version 4. Sunderland (MA): Sinauer Associates.

Thompson JD. 1997. The CLUSTAL_X windows interface: flexible strategies for multiple sequence alignment aided by quality analysis tools. Nucleic Acids Res. 25:4876-4882.

Tsoi KH, Chan T-Y, Chu KH. 2011. Phylogenetic and biogeographic analysis of the spear lobsters Linuparus (Decapoda: palinuridae), with the description of a new species. Zool Anz. 250:302-315.

Vereshchaka AL. 1997. A new family for a deep-sea caridean shrimp from North Atlantic hydrothermal vents. J Mar Biol Assoc UK. 77:425-438.

Watabe H, Hashimoto J. 2002. A new species of the genus Rimicaris (Alvinocarididae: Caridea: Decapoda) from the active hydrothermal vent field, "Kairei Field", on the Central Indian Ridge, the Indian Ocean. Zool Sci. 19:1167-1174.

Webber RW. 2004. A new species of Alvinocaris (Crustacea: Decapoda: Alvinocarididae) and new records of alvinocaridids from hydrothermal vents north of New Zealand. Zootaxa. 444:1-26.

Wicksten MK. 2010. Lebbeus laurentae: a replacement name for Lebbeus carinatus de Saint Laurent, 1984 (Decapoda: Caridea: Hippolytidae) and a redescription of the species. Proc Biol Soc Wash. 123:196-203. 
Williams AB, Chace FA Jr. 1982. A new caridean shrimp of the family Bresiliidae from thermal vents of the Galapagos Rift. J Crust Biol. 21:133-147.

Williams AB, Dobbs FC. 1995. A new genus and species of caridean shrimp (Crustacea: decapoda: bresiliidae) from hydrothermal vents on Loihi Seamount, Hawaii. Proc Biol Soc Wash. 108:228-237.

Williams AB, Rona PA. 1986. Two new caridean shrimps (Bresiliidae) from a hydrothermal field on the Mid-Atlantic Ridge. J Crust Biol. 6:446-462.

Yang CH, Chan TY, Chu KH. 2010. Two new species of the "Heterocarpus gibbosus Bate, 1888" species group (Crustacea: decapoda: Pandalidae) from the western Pacific and north-western Australia. Zootaxa. 2372:206-220.

Zelnio K, Hourdez S. 2009. A new species of Alvinocaris (Crustacea: decapoda: caridea: alvinocarididae) from hydrothermal vents at the Lau Basin, southwest Pacific, and a key to the species of Alvinocarididae. Proc Biol Soc Wash. 122:52-71.

Zelnio K, Thaler AD, Jones RE, Saleu W, Schultz TF, Van Dover CL, Carlsson J. 2010. Characterization of nine polymorphic microsatellite loci in Chorocaris sp. (Crustacea, Caridea, Alvinocarididae) from deep-sea hydrothermal vents. Coverv Genet Resour. 2:223-226. 